\title{
Characterization of biofilm-like structures formed by Pseudomonas aeruginosa in a synthetic mucus medium
}

\author{
Cecily L Haley, Jane A Colmer-Hamood and Abdul N Hamood*
}

\begin{abstract}
Background: The accumulation of thick stagnant mucus provides a suitable environment for the growth of Pseudomonas aeruginosa and Staphylococcus aureus within the lung alveoli of cystic fibrosis (CF) patients. These infections cause significant lung damage, leading to respiratory failure and death. In an artificial mucin containing medium ASM+, P. aeruginosa forms structures that resemble typical biofilms but are not attached to any surface. We refer to these structures as biofilm like structures (BLS). Using ASM+ in a static microtiter plate culture system, we examined the roles of mucin, extracellular DNA, environmental oxygen $\left(\mathrm{EO}_{2}\right)$, and quorum sensing $(\mathrm{QS})$ in the development of biofilm-like structures (BLS) by $P$. aeruginosa; and the effect of $\mathrm{EO}_{2}$ and $P$. aeruginosa on $S$. aureus BLS.

Results: Under $20 \% \mathrm{EO}_{2}$, P. aeruginosa strain PAO1 produced BLS that resemble typical biofilms but are confined to the ASM+ and not attached to the surface. Levels of mucin and extracellular DNA within the ASM+ were optimized to produce robust well developed BLS. At 10\% $\mathrm{EO}_{2}, \mathrm{PAO} 1$ produced thicker, more developed BLS, while under $0 \%$ $\mathrm{EO}_{2}$, BLS production was diminished. In contrast, the S. aureus strain AH133 produced well-developed BLS only under $20 \% \mathrm{EO}_{2}$. In PAO1, loss of the QS system genes rhll and rhIR affected the formation of BLS in ASM+ in terms of both structure and architecture. Whether co-inoculated into ASM+ with AH133, or added to established AH133 BLS, PAO1 eliminated AH133 within 48-56 h.

Conclusions: The thick, viscous ASM+, which contains mucin and extracellular DNA levels similar to those found in the CF lung, supports the formation of biofilm-like structures similar to the aggregates described within CF airways. Alterations in environmental conditions or in the QS genes of $P$. aeruginosa, as occurs naturally during the progression of CF lung infection, affect the architecture and quantitative structural features of these BLS. Thus, ASM + provides an in vitro medium in which the effect of changing levels of substances produced by the host and the bacteria can be analyzed to determine the effect on such structures and on the susceptibility of the bacteria within the BLS to various treatments.
\end{abstract}

\section{Background}

Cystic fibrosis (CF), an inherited disorder caused by mutations in the gene that encodes the cystic fibrosis transmembrane conductance regulator, affects approximately 30,000 Americans, primarily those of Northern European origin [1,2]. These mutations cause a deficiency in chloride secretion with ensuing accumulation of thick, stagnant mucus within the lung alveoli of the patients [1-4]. Nutrients in the thick mucus facilitate the

\footnotetext{
*Correspondence: abdul.hamood@ttuhsc.edu

Department of Immunology and Molecular Microbiology, Texas Tech University Health Sciences Center, School of Medicine, Lubbock TX, USA
}

colonization of various bacterial pathogens, including Pseudomonas aeruginosa, Staphylococcus aureus, and Haemophilus influenzae [3,5]. Colonization by these pathogens elicits a strong host inflammatory response which leads to destruction of the lung tissue and, ultimately, death from respiratory failure [1,6,7]. P. aeruginosa is one of the significant pathogens in chronic lung infections of CF patients $[1,8]$.

Among the different factors that contribute to the virulence of $P$. aeruginosa is its ability to form a biofilm, a community within which bacteria are attached to a substratum or to each other [9]. Within the biofilm, the

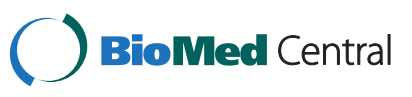


bacteria are surrounded by extracellular polymeric substance (EPS), which protects them from the effects of the host immune system and from diverse antibiotics [10-12]. Biofilm development occurs in stages that require specific bacterial factors at each stage. For example, during the initial (attachment) stage of biofilm formation, bacteria depend on both the flagellummediated swimming motility and the pili-mediated twitching motility [13]. A number of $P$. aeruginosa infections are associated with biofilm formation, including chronic otitis media, heart valve endocarditis, and chronic lung infections in CF patients $[9,14]$.

Previously, studies have described synthetic mucincontaining artificial sputum media (ASM) that mimics the thick mucus within the lung of CF patients $[15,16]$. When grown in ASM, P. aeruginosa formed in tight microcolonies suspended within the medium rather than attached to the surface or free swimming as in standard broth media $[15,16]$. Mucin is the main component of secreted mucus, which also contains a large number of plasma and non-plasma proteins, carbohydrates, amino acids, nucleic acids, lipids, and electrolytes $[17,18]$. It has been shown that mucin- $P$. aeruginosa interactions promote biofilm formation in the continuous culture flowthrough system [19].

In this study, we utilized a static microtiter plate culture system to investigate the effect of different conditions on the development of $P$. aeruginosa biofilms in mucus medium. Within the medium, $P$. aeruginosa strain PAO1 formed structures that are biofilm-like, but are not attached to the surface. The amount of mucin and extracellular DNA in the medium, as well as the level of environmental oxygen $\left(\mathrm{EO}_{2}\right)$, are critical for the development of these biofilm-like structures (BLS). Additionally, one of the $P$. aeruginosa quorum sensing systems, $r h l$, affects formation of the BLS. Furthermore, as it develops its BLS, P. aeruginosa eliminates already established $S$. aureus BLS by a bactericidal mechanism.

\section{Results}

Previous studies described a synthetic medium, ASM, which closely mimics the sputum of CF patients $[15,16]$. When grown in ASM, PAO1 formed clusters, or microcolonies, that are attached to the components of the ASM but not the abiotic surface [16]. In this study, we analyzed the influence of different conditions on the formation of these unique structures. We then examined the growth of the $P$. aeruginosa strain PAO1/pMRP9-1 in the static microtiter plate culture system using ASM+. First, we eliminated the possibility that the addition of antibiotics (either carbenicillin or erythromycin) to ASM+ to maintain the GFP plasmid had an adverse effect on either the growth of the tested strains or BLS development by these strains (data not shown). Inoculated plates were incubated at $37^{\circ} \mathrm{C}$ under $20 \% \mathrm{EO}_{2}$. In situ CLSM of the gelatinous masses at $48 \mathrm{~h}$ revealed the formation of structures composed of numerous coalescing microcolonies that closely resemble mature well-developed PAO1 biofilms (Figure 1A, B). Quantitative analysis of the BLS using the COMSTAT program [20], supported these findings: a total biovolume of $6.52 \pm 0.43 \mu \mathrm{m}^{3} / \mu \mathrm{m}^{2}$ and a mean thickness of $11.57 \pm 0.28 \mu \mathrm{m}$ was seen at $48 \mathrm{~h}$ (Table 1). Unlike the development of PAO1 biofilms in other media, these unique suspended biofilm-like structures (BLS) are induced only within the gelatinous mass, as PAO1 did not form any biofilm on the surface of the microtiter well (Figure 1C). To further confirm these results, we grew PAO1 as described above but inserted a small plastic coverslip within the well of the microtiter plate. PAO1 again formed the unique BLS but failed to form any biofilm on the plastic surface (data not shown). In contrast, when we repeated the experiment with TSBDC, an irondeficient medium in which $P$. aeruginosa grows planktonically and develops conventional biofilm, PAO1 formed a thick mature biofilm attached to the coverslip surface (data not shown).

\section{Extended incubation time enhances the formation of the BLS}

One condition that may influence the development of the BLS in the ASM+ is length of incubation. Since the growth of PAO1 in ASM+ appears similar to the macrocolonies reported within the lungs of CF patients with chronic $P$. aeruginosa infection [21], we inoculated ASM+ with PAO1/pMRP9-1 as described above and incubated the cultures in $20 \% \mathrm{EO}_{2}$ at $37^{\circ} \mathrm{C}$ for up to $16 \mathrm{~d}$. From days 2 to 6 , the BLS gradually developed to resemble a complete, mature and well developed biofilm (Figure 2A). Three-dimensional (3-D) images constructed from the CLSM scans clearly show the gradual increase in the size and the thickness of the BLS (Figure 2B). Structural analysis revealed that between 2-3 and 26 days, the BLS significantly increased in total biovolume and mean thickness (Tables 1 and 2). In contrast, portions of the BLS that are exposed to nutrients (the surface to biovolume ratio) and roughness coefficient values were significantly reduced (Tables 1 and 2). The total surface area was significantly $(\mathrm{P}<0.0001)$ decreased between 2-6 days only (Table 1 ). For the 16-d growth experiments, we maintained the growth of the PAO1 BLS by adding fresh ASM+ to the media remaining in the wells to maintain the original volume every $4 \mathrm{~d}$ to replace volume lost to evaporation. At $16 \mathrm{~d}$, PAO1 BLS appears to be greater than at any time during the course of the experiment (Figure 3). Due to enhanced growth by the replacement of the medium, new microcolonies appear to have developed atop the underlying thick 

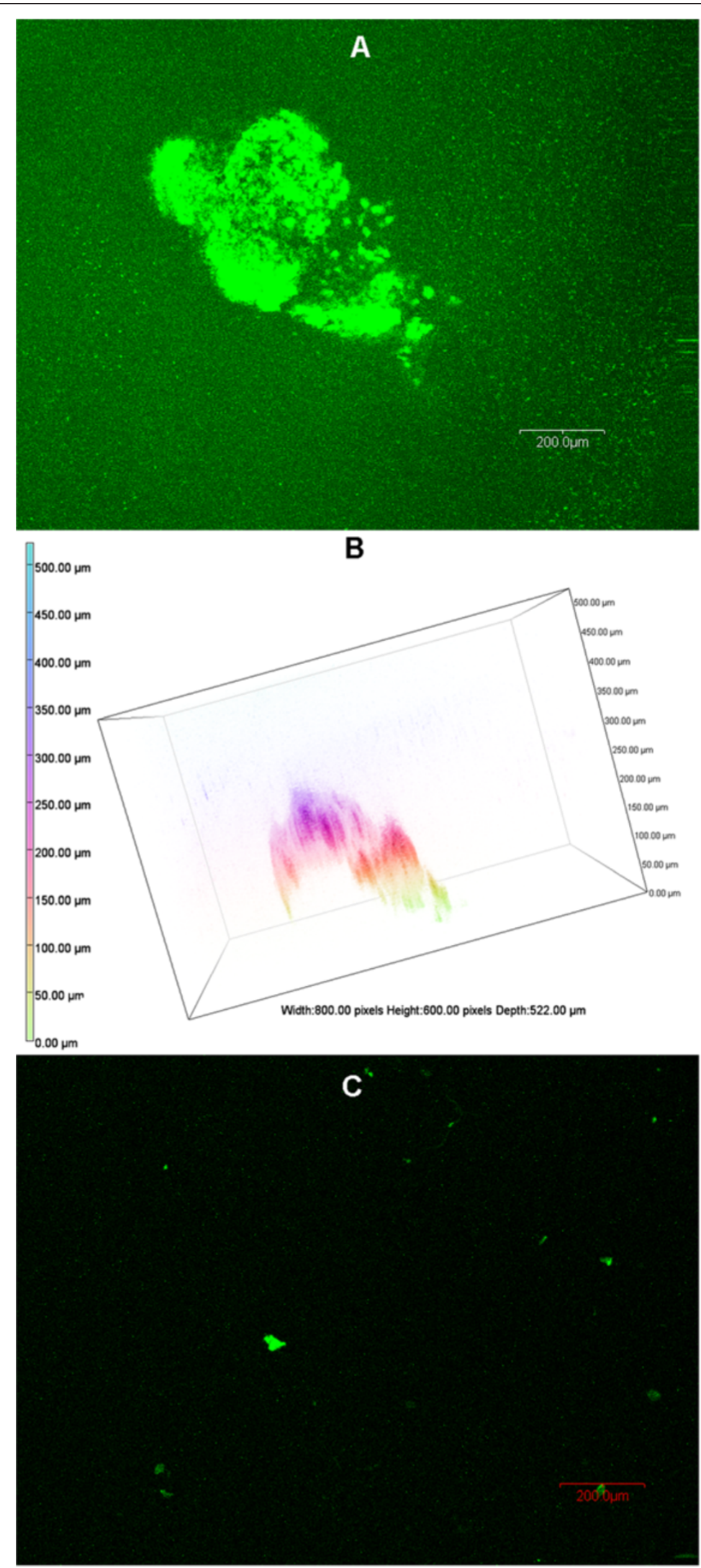

Figure 1 (See legend on next page.) 
(See figure on previous page.)

Figure 1 P. aeruginosa PAO1 forms BLS within the ASM+. After $48 \mathrm{~h}$ of growth at $37^{\circ} \mathrm{C}$ under $20 \% \mathrm{EO}_{2} / \mathrm{static}$ conditions, PAO1/pMRP9-1 developed BLS that were confined to the ASM+ and not attached to the surface of the microtiter plate. The composition of the ASM+ and the bacterial inoculation are described in Methods. The gelatinous mass containing the BLS was visualized in situ by CLSM. (A) CLSM micrograph of the PAO1/pMRP9-1 BLS; magnification, 10X; bar, $200.00 \mathrm{~nm}$. (B) 3-D image analysis revealing the architecture of the BLS shown in (A); box, 800.00 pixels (px) W x 600 px H; bar, 100 px. (C) CLSM micrograph of the well bottom after the removal of the gelatinous mass showing no attached bacteria or biofilm (the scattered fluorescence observed is due to autofluorescing debris).

growth (Figure 3). Alternatively, these microcolonies may represent detached segments of the well developed biofilm (Figure 3). Such detachment may occur mechanically and would not represent the well known bacterial dispersion phenomenon. In bacterial dispersion, individual planktonic cells and not biofilm segments are released from the mature biofilm [14]. No biofilm attached to the surface of the well of the microtiter plate at any time point throughout the experiment (data not shown). These results suggest that dynamic changes within occur PAO1 BLS during growth in ASM+ over an extended period of time.

\section{Mucin and DNA concentrations influence the development of the PAO1 BLS}

Mucin, together with extracellular DNA, contributes to the viscosity of the CF sputum $[17,18]$. Mucin is one of the main components of ASM+. To determine if variations in the amount of mucin or DNA in ASM+ would affect the formation of the BLS, we adjusted the concentration of each component individually. With $0.5 \mathrm{X}$ mucin $(2.5 \mathrm{mg} /$ $\mathrm{ml})$ or $2 \mathrm{X}$ mucin $(10 \mathrm{mg} / \mathrm{ml})$, PAO1 formed BLS, but the architecture was more diffuse in appearance than BLS seen with $1 \mathrm{X}$ mucin $(5 \mathrm{mg} / \mathrm{ml})$ (Figure 4). In general, varying the mucin concentration altered the structural parameters of PAO1 BLS. Either reduced or elevated mucin concentrations increased the biovolume and thickness significantly while the roughness was significantly decreased in both cases (Tables 1 and 2). Additionally, 0.5X mucin significantly increased the total surface area, while $2 \mathrm{X}$ mucin reduced the surface to biovolume ratio significantly (Table 2). We eliminated the possibility that variations in the amount of mucin simply affected the growth of PAO1 by determining $\mathrm{CFU} / \mathrm{ml}$ for PAO1 grown in $\mathrm{ASM}+$ with

Table 1 Effect of time and environmental variables on PA01/pMRP9-1 BLS

\begin{tabular}{|c|c|c|c|c|c|c|}
\hline Variable & 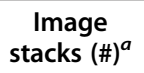 & $\begin{array}{l}\text { Total biovolume } \\
\qquad\left(\mu \mathrm{m}^{3} / \mu \mathrm{m}^{2}\right)^{b}\end{array}$ & $\begin{array}{l}\text { Mean thickness } \\
(\mu \mathrm{m})^{c}\end{array}$ & $\begin{array}{l}\text { Roughness } \\
\text { coefficient }^{d}\end{array}$ & $\begin{array}{c}\text { Total surface } \\
\text { area } \times 10^{7}\left(\mu \mathrm{m}^{2}\right)^{e}\end{array}$ & $\begin{array}{l}\text { Surface to volume } \\
\text { ratio }\left(\mu \mathrm{m}^{2} / \mu \mathrm{m}^{3}\right)^{f}\end{array}$ \\
\hline \multicolumn{7}{|c|}{ Time (under $20 \% \mathrm{EO}_{2}$ ) } \\
\hline $48 h$ & 10 & $6.52 \pm 0.43$ & $11.6 \pm 0.28$ & $0.53 \pm 0.02$ & $1.65 \pm 0.24$ & $1.54 \pm 0.10$ \\
\hline $72 \mathrm{~h}$ & 10 & $11.1 \pm 0.40$ & $15.5 \pm 0.23$ & $0.18 \pm 0.02$ & $2.15 \pm 0.03$ & $1.01 \pm 0.04$ \\
\hline $6 d$ & 10 & $18.2 \pm 0.32$ & $17.8 \pm 0.06$ & $0.02 \pm 0.00$ & $0.96 \pm 0.12$ & $0.28 \pm 0.04$ \\
\hline \multicolumn{7}{|c|}{ Mucin concentration ( $3 \mathrm{~d}$ under $20 \% \mathrm{EO}_{2}$ ) } \\
\hline $1 X$ & 10 & $11.1 \pm 0.40$ & $15.5 \pm 0.23$ & $0.18 \pm 0.02$ & $2.15 \pm 0.03$ & $1.01 \pm 0.04$ \\
\hline $0.5 X$ & 10 & $13.5 \pm 0.24$ & $17.0 \pm 0.05$ & $0.08 \pm 0.00$ & $2.44 \pm .045$ & $0.94 \pm 0.03$ \\
\hline $2 X$ & 10 & $15.4 \pm 0.35$ & $17.3 \pm 0.08$ & $0.06 \pm 0.00$ & $1.97 \pm .098$ & $0.67 \pm 0.05$ \\
\hline \multicolumn{7}{|c|}{ DNA concentration ( $3 \mathrm{~d}$ under $20 \% \mathrm{EO}_{2}$ ) } \\
\hline $1 X$ & 10 & $11.1 \pm 0.40$ & $15.5 \pm 0.23$ & $0.18 \pm 0.02$ & $2.15 \pm 0.03$ & $1.01 \pm 0.04$ \\
\hline $0.5 X$ & 10 & $2.42 \pm 0.54$ & $4.37 \pm 1.37$ & $1.33 \pm 0.20$ & $0.76 \pm .220$ & $1.55 \pm 0.15$ \\
\hline $1.5 X$ & 10 & $2.48 \pm 0.22$ & $5.52 \pm 0.64$ & $1.07 \pm 0.07$ & $0.96 \pm .086$ & $2.02 \pm 0.01$ \\
\hline \multicolumn{7}{|c|}{ Oxygen concentration $\left(\mathrm{EO}_{2}\right)^{g}$} \\
\hline $20 \%$ & 10 & $11.1 \pm 0.40$ & $15.5 \pm 0.23$ & $0.18 \pm 0.02$ & $2.15 \pm 0.03$ & $1.01 \pm 0.04$ \\
\hline $10 \%$ & 10 & $19.4 \pm 0.28$ & $17.9 \pm 0.04$ & $0.01 \pm 0.00$ & $0.46 \pm 0.12$ & $0.13 \pm 0.03$ \\
\hline $0 \%$ & 10 & $0.28 \pm 0.19$ & $0.41 \pm 0.27$ & $1.94 \pm 0.04$ & $0.07 \pm 0.06$ & $1.75 \pm 0.30$ \\
\hline
\end{tabular}

${ }^{a}$ Each experiment was done in duplicate. Two 10-image stacks were obtained from random positions within the BLs. A total of 40 -image stacks were analyzed were analyzed using the COMSTAT program [20]. Values represent the mean \pm SEM.

${ }^{b}$ Estimates the biomass of the BLS.

${ }^{c}$ Measures spatial size of the BLS.

${ }^{d}$ Assessment of the variation in the thickness of the BLS, or BLS heterogeneity.

${ }^{e}$ Total of the area occupied in each image stack.

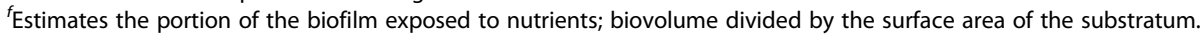

${ }^{g} 20 \%$, aerobic; $10 \%$, microaerobic; $0 \%$, anaerobic; cultures were grown for $3 \mathrm{~d}$, except $0 \% \mathrm{EO}_{2}$ for $6 \mathrm{~d}$. 


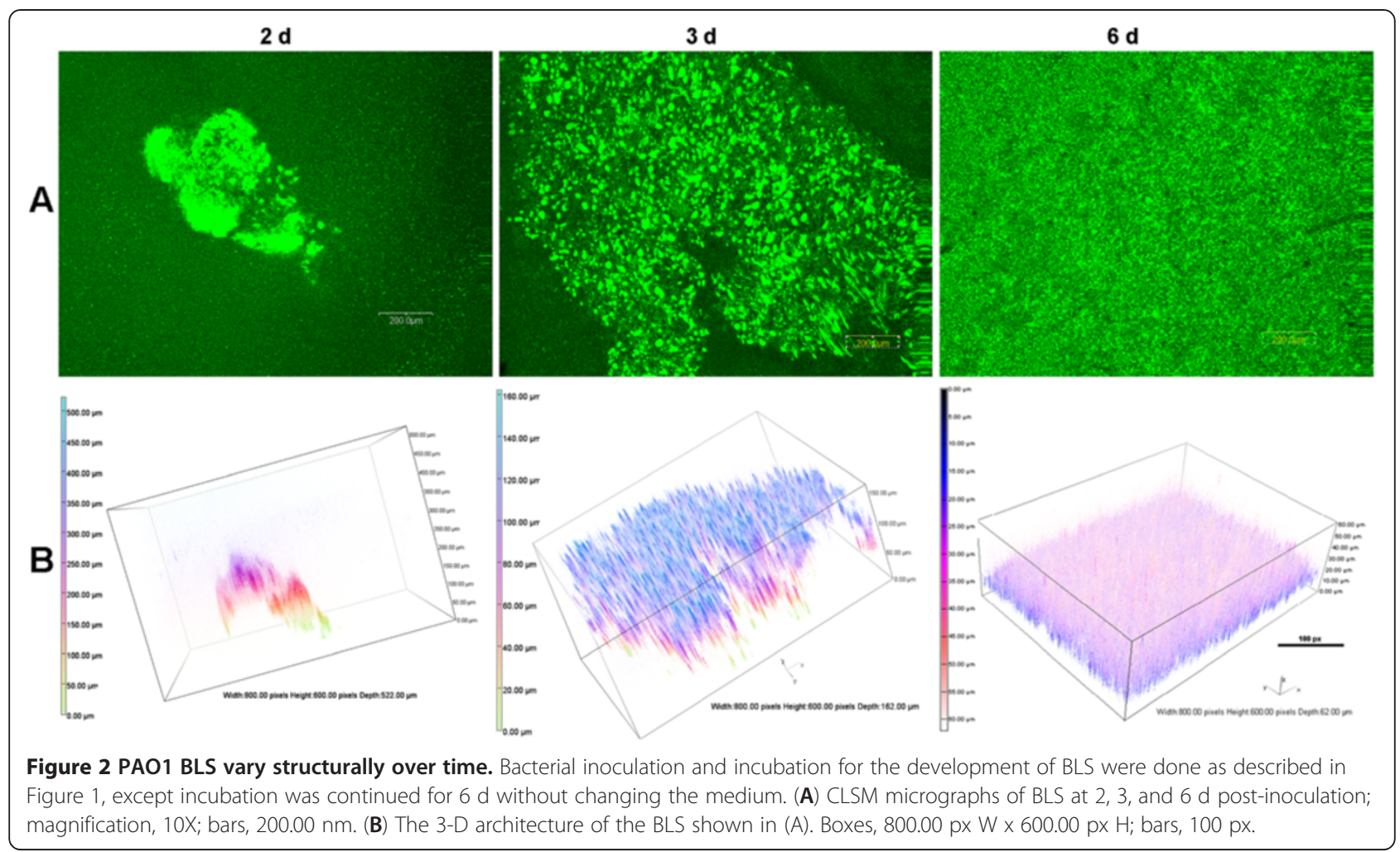

$1 \mathrm{X}, 0.5 \mathrm{X}$ or $2 \mathrm{X}$ mucin. After $3 \mathrm{~d}$, comparable growth was observed in each condition, approximately $5 \times 10^{9} \mathrm{CFU} /$ $\mathrm{ml}$ (Figure 4D).

Variation in the amount of DNA produced more dramatic differences. When the amount of DNA was reduced to $0.5 \mathrm{X}(2 \mathrm{mg} / \mathrm{ml})$, BLS were detected but confined to a small area of the gelatinous mass rather than spread throughout the medium as observed with 1X DNA (Figure 5A, B). When we increased the amount of DNA to $1.5 \mathrm{X}(6 \mathrm{mg} / \mathrm{ml})$, individual cells were found scattered throughout the gelatinous medium, but no defined structures were detected (Figure 5C). The total

Table 2 Significance of differences in values presented in Table 1

\begin{tabular}{|c|c|c|c|c|c|c|}
\hline Variable $^{a}$ & 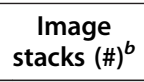 & $\begin{array}{c}\text { Total biovolume } \\
\left(\mu \mathrm{m}^{3} / \mu \mathrm{m}^{2}\right)^{b}\end{array}$ & $\begin{array}{l}\text { Mean thickness } \\
(\mu \mathrm{m})^{b}\end{array}$ & $\begin{array}{l}\text { Roughness } \\
\text { coefficient }^{b}\end{array}$ & $\begin{array}{c}\text { Total surface } \\
\text { area } \times 10^{7}\left(\mu \mathrm{m}^{2}\right)^{b}\end{array}$ & $\begin{array}{l}\text { Surface to volume } \\
\text { ratio }\left(\mu \mathrm{m}^{2} / \mu \mathrm{m}^{3}\right)^{b}\end{array}$ \\
\hline \multicolumn{7}{|c|}{ Time (under $20 \% \mathrm{EO}_{2}$ ) } \\
\hline $3 d$ vs. $2 d$ & 10 & Increase 0.0002 & Increase $<0.0001$ & Decrease $<0.0001$ & $\mathrm{NS}^{d}$ & Decrease 0.0027 \\
\hline $6 d$ vs. $2 d$ & 10 & Increase 0.0002 & Increase 0.0002 & Decrease $<0.0001$ & Decrease $<0.0001$ & Decrease $<0.0001$ \\
\hline \multicolumn{7}{|c|}{ Mucin concentration ( $3 \mathrm{~d}$ under $20 \% \mathrm{EO}_{2}$ ) } \\
\hline $2.0 X$ vs. $1 X$ & 10 & Increase 0.0002 & Increase 0.0003 & Decrease 0.0006 & NS & Decrease 0.0018 \\
\hline $0.5 X$ vs. $1 X$ & 10 & Increase 0.0019 & Increase 0.0007 & Decrease 0.0011 & Increase 0.0290 & NS \\
\hline \multicolumn{7}{|c|}{ DNA concentration ( $3 \mathrm{~d}$ under $20 \% \mathrm{EO}_{2}$ ) } \\
\hline $1.5 X$ vs. $1 X$ & 10 & Decrease $<0.0001$ & Decrease $<0.0001$ & Increase $<0.0001$ & Decrease $<0.0001$ & Increase $<0.0001$ \\
\hline $0.5 X$ vs. $1 X$ & 10 & Decrease $<0.0001$ & Decrease 0.0002 & Increase 0.0013 & Decrease 0.0008 & Increase 0.0124 \\
\hline \multicolumn{7}{|c|}{ Oxygen concentration $\left(\mathrm{EO}_{2}\right)^{e}$} \\
\hline $10 \%$ vs. $20 \%$ & 10 & Increase $<0.0001$ & Increase $<0.0001$ & Decrease $<0.0001$ & Decrease $<0.0001$ & Decrease $<0.0001$ \\
\hline $0 \%$ vs. $20 \%$ & 10 & Decrease $<0.0001$ & Decrease $<0.0001$ & Increase $<0.0001$ & Decrease 0.0287 & Increase 0.0482 \\
\hline
\end{tabular}

${ }^{a}$ All strains carry pMRP9-1 and were grown without shaking.

${ }^{b}$ See Table 1 for description of parameters.

'Significant change with $P$ value indicated below direction of change.

${ }^{d} \mathrm{NS}$, no significant difference.

${ }^{e} 20 \%$, aerobic; $10 \%$, microaerobic; $0 \%$, anaerobic; cultures were grown for $3 \mathrm{~d}$, except $0 \% \mathrm{EO}_{2}$ for $6 \mathrm{~d}$. 

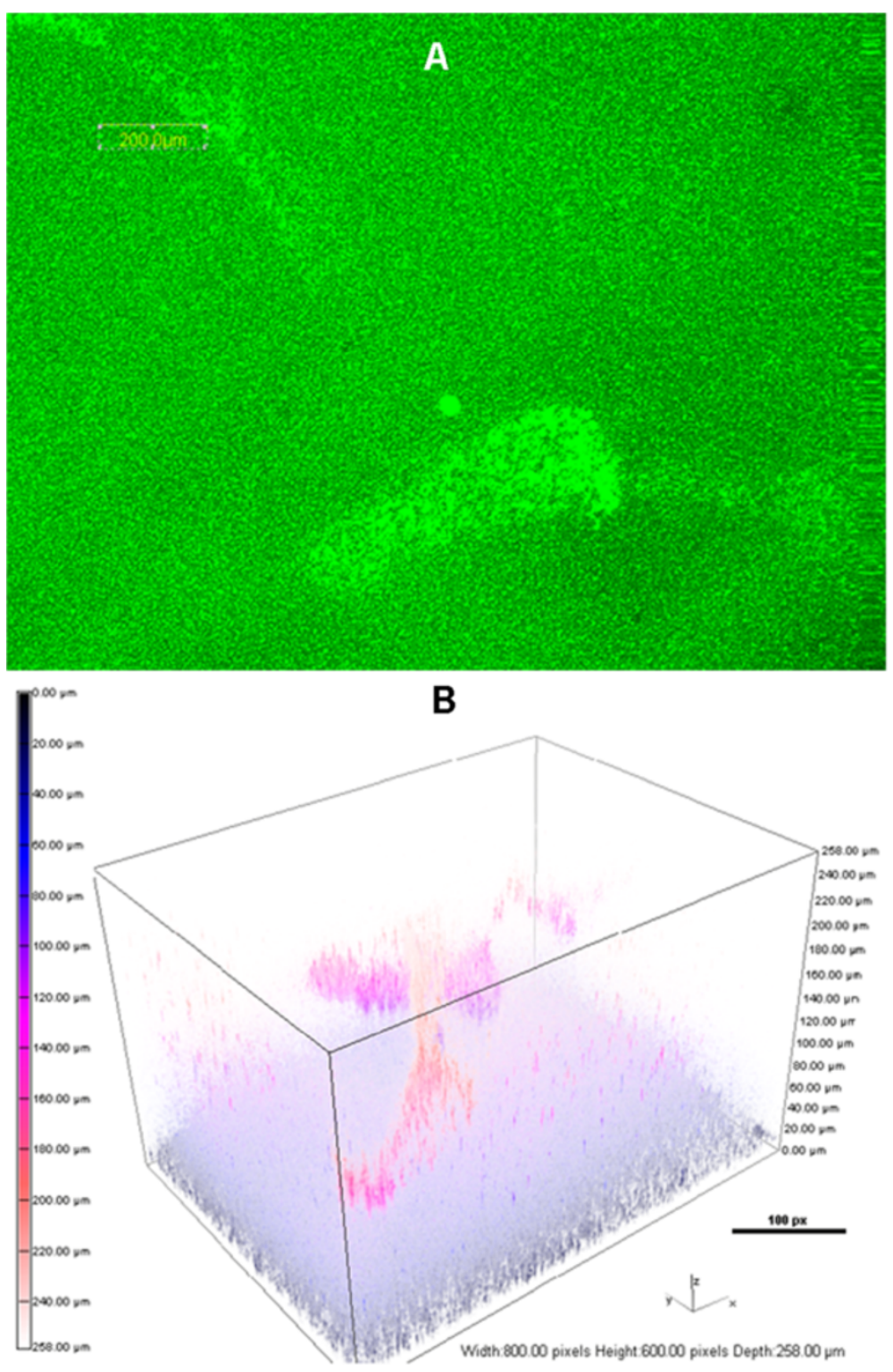

Figure 3 Extending incubation to $16 \mathrm{~d}$ enhances the formation of PAO1 BLS. Bacterial inoculation and incubation for the development of BLS were done as described in Figure 1, except fresh ASM+ was added to the wells at 4-d intervals to replace lost volume. (A) CLSM micrographs of BLS at $16 \mathrm{~d}$ post-inoculation; magnification, 10X; bar, $200.00 \mathrm{~nm}$. (B) The 3-D architecture of the BLS shown in (A). Boxes, $800.00 \mathrm{px} \mathrm{W} \times 600.00$ px H; bar, 100 px.

biovolume, mean thickness, and total surface area of BLS developed in the presence of either $0.5 \mathrm{X}$ or $1.5 \mathrm{X}$ DNA were significantly less than those of BLS developed in the presence of 1X DNA (Tables 1 and 2). In contrast, the values of the roughness coefficient and surface to biovolume ratio were significantly increased (Table 2). This resembles the initial stage of biofilm development on an abiotic surface in which $P$. aeruginosa colonizes the surface and forms a single monolayer. As for the variations in mucin, we enumerated the CFU/ml for PAO1 grown in $\mathrm{ASM}+$ with $1 \mathrm{X}, 0.5 \mathrm{X}$ or $1.5 \mathrm{X} \mathrm{DNA}$, and again, comparable levels of growth were obtained in each condition (Figure 5D).

\section{The level of $\mathrm{EO}_{2}$ affects the formation of BLS}

Previous studies suggested that within the lung alveoli of CF patients, $P$. aeruginosa survives and grows under an oxygen gradient of $10 \% \mathrm{EO}_{2}$ to $0 \% \mathrm{EO}_{2}[5,21,22]$. The experiments described above were conducted under $20 \%$ $\mathrm{EO}_{2}$. Therefore, we compared the development of the PAO1/pMRP9-1 BLS in ASM+ under 20\%, 10\% and 0\% $\mathrm{EO}_{2}$. Cultures were incubated for $3 \mathrm{~d}$ under $20 \%$ and 


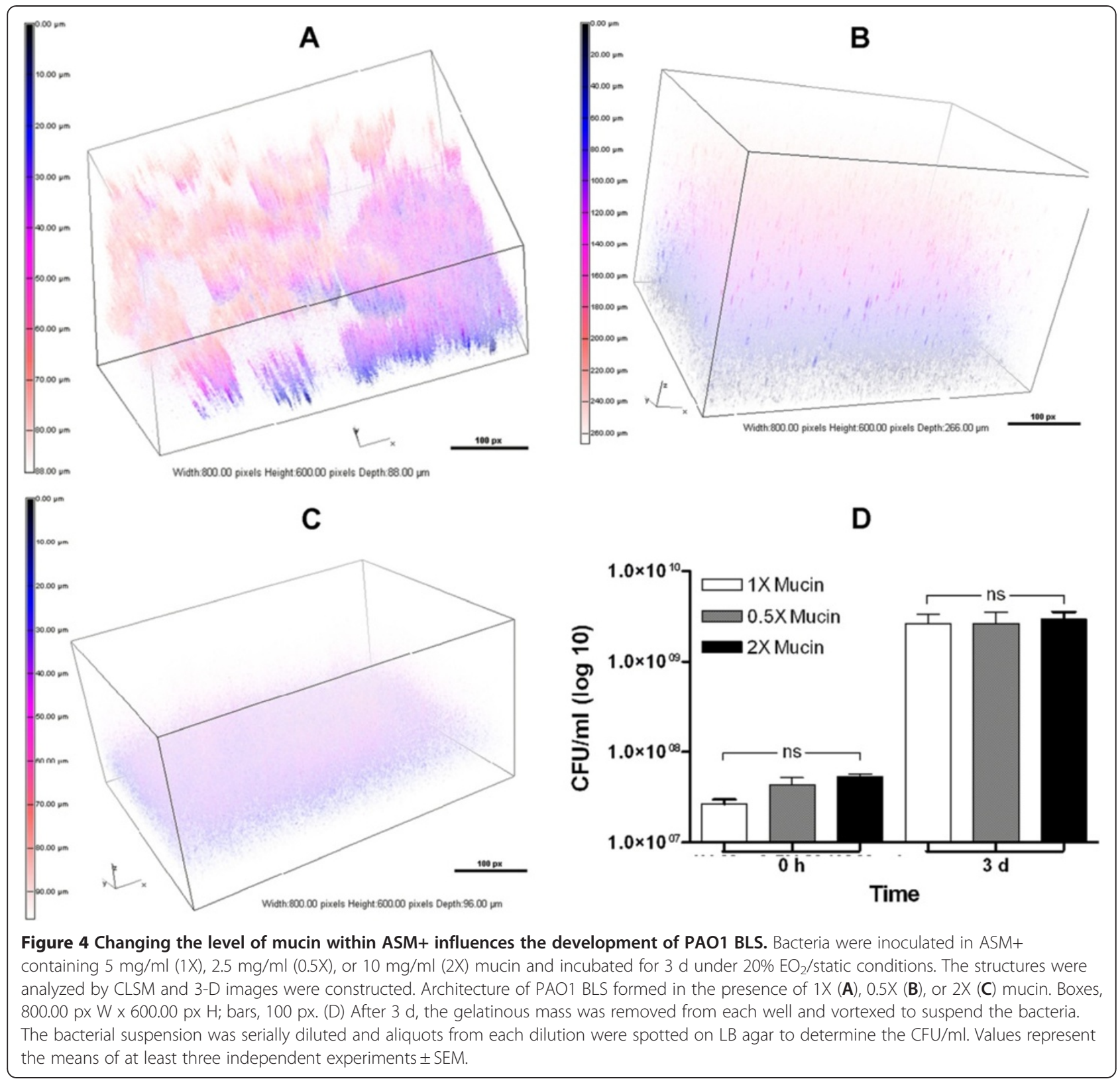

$10 \% \mathrm{EO}_{2}$. For growth under $0 \% \mathrm{EO}_{2}$, ASM+ was supplemented with $10 \%$ potassium nitrate as a terminal electron acceptor [5] and incubated for $6 \mathrm{~d}$. Under anaerobic conditions, $P$. aeruginosa grows rapidly using anaerobic respiration, which requires nitrate $\left(\mathrm{NO}_{3}^{-}\right)$, nitrite $\left(\mathrm{NO}_{2}^{-}\right)$, or nitrous oxide $\left(\mathrm{N}_{2} \mathrm{O}\right)$ as alternative terminal electron acceptors [5]. As $P$. aeruginosa penetrate the thick mucus within the lung alveoli of CF patients and reach the hypoxic zone, they transit from aerobic to anaerobic metabolism and begin to utilize the $\mathrm{NO}_{3}^{-}$and or $\mathrm{NO}_{2}^{-}$present within the $\mathrm{CF}$ mucus [5]. Compared with structures that formed under $20 \% \mathrm{EO}_{2}$, those that formed under $10 \% \mathrm{EO}_{2}$ appeared more developed by CLSM (Figure 6A), much more dense and reaching almost twice the maximum depth (Figure 6B). Quantitative structural analysis by COMSTAT confirmed that compared with $20 \% \mathrm{EO}_{2}$, the growth of PAO1 under $10 \% \mathrm{EO}_{2}$ significantly increased the biovolume and mean thickness of the BLS (Tables 1 and 2). However, the values for the roughness coefficient, surface area, and surface to biovolume ratio were significantly reduced (Tables 1 and 2). In contrast, structures developed under $0 \% \mathrm{EO}_{2}$ were smaller and limited to only a small portion of the gelatinous mass within the well (Figure 6). These structures were much less developed than BLS formed under $20 \% \mathrm{EO}_{2}$ as shown by the significantly reduced mean thickness, total biovolume, and surface area (Tables 1 and 2). However, the roughness coefficient and 


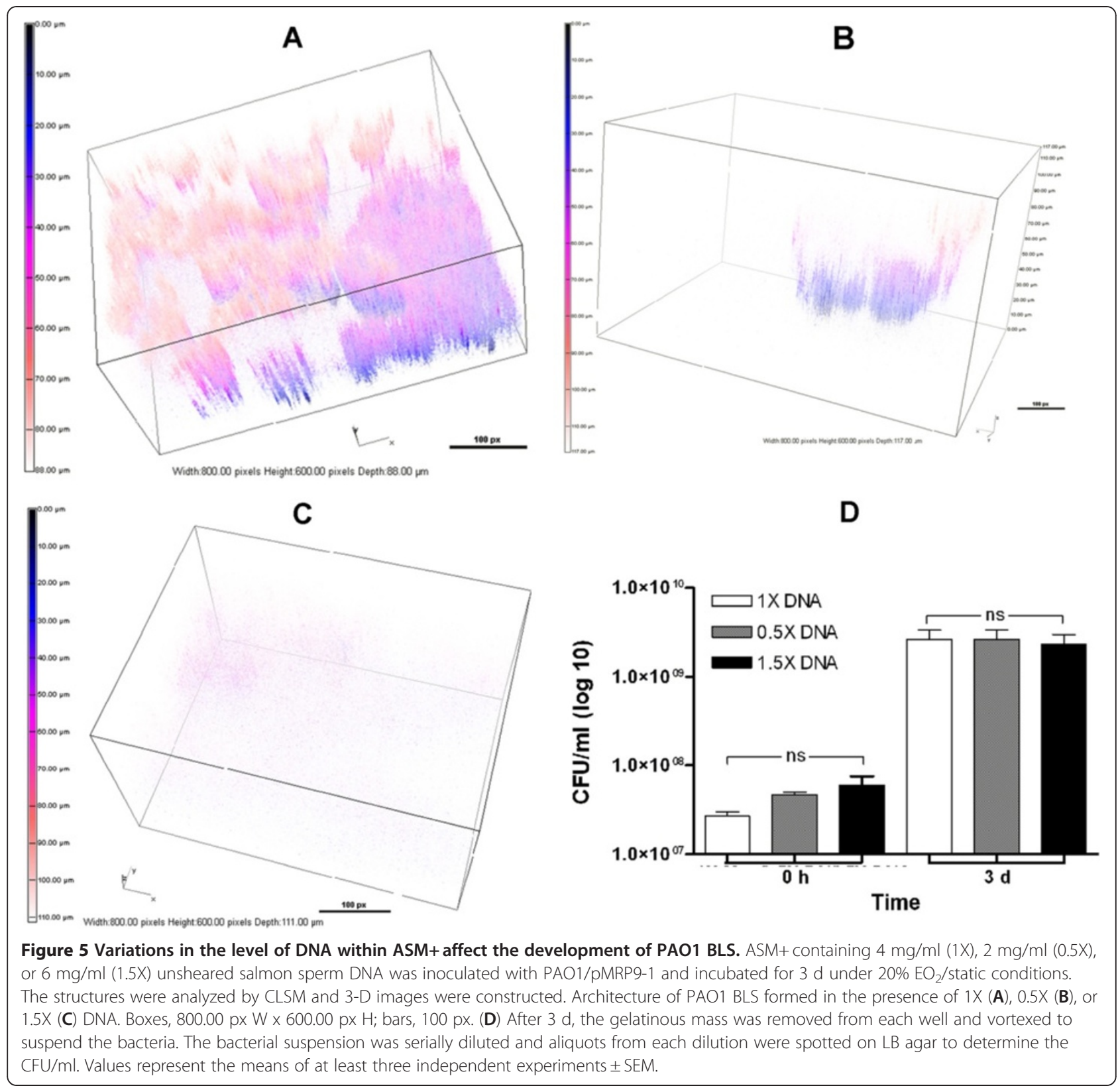

surface to biovolume were significantly increased (Tables 1 and 2). These results suggest that in ASM+, maximum development of the PAO1 BLS occurs under $10 \% \mathrm{EO}_{2}$, whereas the growth under $0 \% \mathrm{EO}_{2}$ severely limits their development. Based on this finding, we conducted the rest of the PAO1 BLS analysis under $10 \% \mathrm{EO}_{2}$.

\section{Different $P$. aeruginosa strains produce dissimilar BLS in ASM+}

As there are many strains of $P$. aeruginosa that differ in their ability to produce conventional biofilm, we compared the development of the BLS by PAK and
PA103 under $10 \% \mathrm{EO}_{2}$ with that of PAO1. These strains were originally isolated from infected patients and have been extensively utilized in in vitro and in vivo virulence studies [10,23-26]. Additionally, we examined the $P$. aeruginosa strain CI-4, a clinical isolate obtained from a patient with a chronic lower respiratory infection (30 days with the same strain) [27]. These strains were transformed with pMRP9-1 (for GFP expression) and grown in ASM+ for $3 \mathrm{~d}$ and the BLS analyzed as described in Methods. None of the PAK BLS parameters were significantly different from those of PAO1 BLS (Tables 3 and 4; Figure 7). With respect to PA103 BLS, only the total biovolume and 


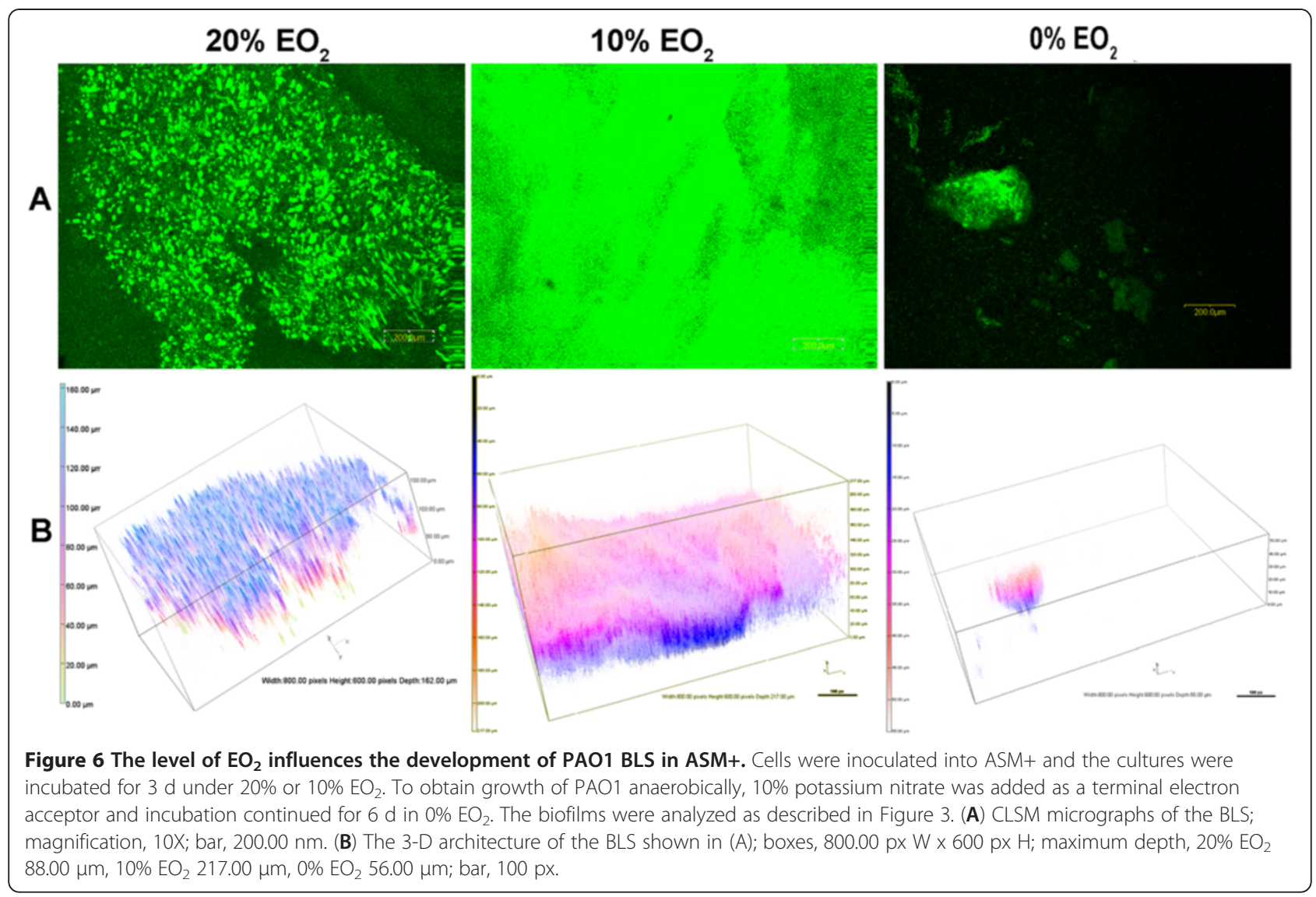

mean thickness were significantly reduced in comparison with PAO1 BLS (Table 3 and 4; Figure 7). In contrast, CI-4 produced BLS that were significantly lower than those of PAO1 BLS in total biovolume, mean thickness, and total surface area but significantly higher than PAO1 in roughness coefficient and surface

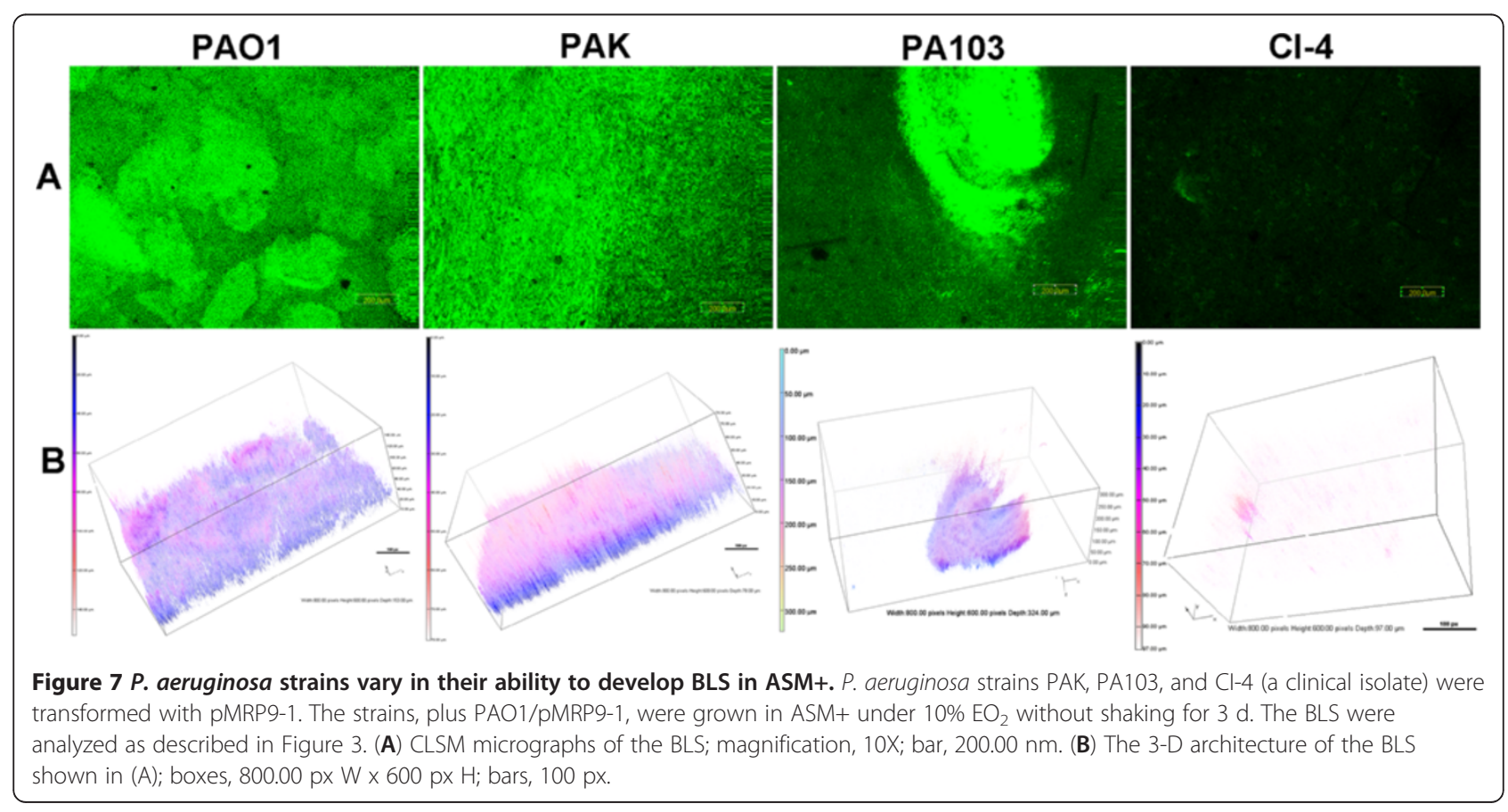


Table 3 Structural analysis of BLS formed by $P$. aeruginosa strains and QS mutants

\begin{tabular}{|c|c|c|c|c|c|c|}
\hline Strains $^{a}$ & $\begin{array}{c}\text { Image } \\
\text { stacks }(\#)^{b}\end{array}$ & $\begin{array}{l}\text { Total biovolume } \\
\left(\mu \mathrm{m}^{3} / \mu \mathrm{m}^{2}\right)^{b}\end{array}$ & $\begin{array}{l}\text { Mean thickness } \\
\qquad(\mu \mathrm{m})^{b}\end{array}$ & $\begin{array}{l}\text { Roughness } \\
\text { coefficient }^{d}\end{array}$ & $\begin{array}{c}\text { Total surface } \\
\text { area } \times 10^{7}\left(\mu \mathrm{m}^{2}\right)^{b}\end{array}$ & $\begin{array}{l}\text { Surface to volume } \\
\text { ratio }\left(\mu \mathrm{m}^{2} / \mu \mathrm{m}^{3}\right)^{b}\end{array}$ \\
\hline \multicolumn{7}{|c|}{ Prototrophs and clinical isolate } \\
\hline PAO1 & 10 & $18.2 \pm 0.69$ & $17.5 \pm 0.12$ & $0.05 \pm 0.01$ & $0.73 \pm 0.23$ & $0.28 \pm 0.07$ \\
\hline PAK & 10 & $13.7 \pm 2.82$ & $13.2 \pm 2.62$ & $0.05 \pm 0.02$ & $0.62 \pm 0.05$ & $0.27 \pm 0.06$ \\
\hline PA103 & 10 & $10.7 \pm 0.08$ & $12.6 \pm 2.13$ & $0.07 \pm 0.03$ & $1.32 \pm 0.50$ & $0.61 \pm 0.21$ \\
\hline $\mathrm{Cl}-4$ & 10 & $0.48 \pm 0.17$ & $0.77 \pm 0.45$ & $1.67 \pm 0.12$ & $0.23 \pm 0.84$ & $2.45 \pm 0.02$ \\
\hline \multicolumn{7}{|c|}{ Quorum-sensing mutants } \\
\hline PAO1 (wt) & 10 & $18.2 \pm 0.69$ & $17.5 \pm 0.12$ & $0.05 \pm 0.01$ & $0.73 \pm 0.23$ & $0.21 \pm 0.07$ \\
\hline PAO-R1 ( $\Delta$ lasR) & 10 & $19.3 \pm 0.43$ & $18.0 \pm 0.00$ & $0.02 \pm 0.00$ & $0.43 \pm 0.15$ & $0.12 \pm 0.04$ \\
\hline PAO-JP1(D/asl) & 10 & $17.6 \pm 1.45$ & $17.8 \pm 0.15$ & $0.02 \pm 0.02$ & $0.65 \pm 0.26$ & $0.22 \pm 0.11$ \\
\hline PDO111 ( $\Delta r h / R)$ & 10 & $7.29 \pm 0.10$ & $8.26 \pm 0.05$ & $0.13 \pm 0.01$ & $1.10 \pm 0.08$ & $0.79 \pm 0.04$ \\
\hline PD0100 ( $\Delta r h / l)$ & 10 & $6.61 \pm 2.25$ & $8.65 \pm 2.49$ & $0.67 \pm 0.12$ & $0.98 \pm 0.14$ & $1.01 \pm 0.23$ \\
\hline PW2798 ${ }^{C}(\Delta p q s A)$ & 10 & $18.4 \pm 0.30$ & $17.7 \pm 0.08$ & $0.03 \pm 0.01$ & $0.70 \pm 0.10$ & $0.20 \pm 0.03$ \\
\hline
\end{tabular}

${ }^{a}$ All strains carry pMRP9-1 and were grown for $3 \mathrm{~d}$ under $10 \% \mathrm{EO}_{2}$ without shaking.

${ }^{b}$ See Table 1 for description of parameters.

'PW2798::pqsA-lac.

to biovolume ratio, indicating dispersal of poorly formed BLS throughout the gelatinous mass (Tables 3 and 4; Figure 7). These results indicate that $P$. aeruginosa strains differ in their ability to produce BLS within the ASM+.

\section{Quorum sensing affects the development of PAO1 BLS in ASM+}

The three quorum sensing (QS) systems las, rhl, and pqs contribute to the development of $P$. aeruginosa biofilms [28-30]. Mutants defective in one or more of these systems failed to form well developed biofilms compared with the PAO1 parent strain [28-30]. Using a conventional biofilm medium (LB broth), we compared the biofilm developed on a plastic cover slip in a microtiter plate well by PAO1 and its lasR, lasI, rhlR, rhlI, and pqsA mutants. With the exception of the medium, the biofilms were developed under the same conditions that we used to develop the BLS. Compared with PAO1, all QS mutants produced reduced biofilms (data not shown). We then examined the contribution of the QS systems to the formation of the PAO1 BLS in ASM+, by comparing the structures formed

Table 4 Significance of differences in values presented in Table 3

\begin{tabular}{|c|c|c|c|c|c|c|}
\hline Variable $^{a}$ & $\begin{array}{c}\text { Image } \\
\text { stacks }(\#)^{b}\end{array}$ & $\begin{array}{l}\text { Total biovolume } \\
\left(\mu \mathrm{m}^{3} / \mu \mathrm{m}^{2}\right)^{b}\end{array}$ & $\begin{array}{l}\text { Mean thickness } \\
(\mu \mathrm{m})^{b}\end{array}$ & $\begin{array}{l}\text { Roughness } \\
\text { coefficient }^{b}\end{array}$ & $\begin{array}{c}\text { Total surface } \\
\text { area } \times 10^{7}\left(\mu \mathrm{m}^{2}\right)^{b}\end{array}$ & $\begin{array}{l}\text { Surface to volume } \\
\operatorname{ratio}\left(\mu \mathrm{m}^{2} / \mu \mathrm{m}^{3}\right)^{b}\end{array}$ \\
\hline \multicolumn{7}{|c|}{ Prototrophs and clinical isolate } \\
\hline PAK vs. PAO1 & 10 & $\mathrm{NS}^{\mathrm{C}}$ & NS & NS & NS & NS \\
\hline PA103 vs. PAO1 & 10 & Decrease $^{d} 0.0004$ & Decrease 0.0313 & NS & NS & NS \\
\hline $\mathrm{Cl}-4$ vs. PAO1 & 10 & Decrease $<0.0001$ & Decrease $<0.0001$ & Increase $<0.0001$ & Decrease 0.0417 & Increase $<0.0001$ \\
\hline \multicolumn{7}{|c|}{ Quorum-sensing mutants } \\
\hline PAO-R1 vs. PAO1 & 10 & NS & Increase 0.0241 & Decrease 0.0172 & NS & NS \\
\hline PAO-JP1 vs. PAO1 & 10 & NS & NS & NS & NS & NS \\
\hline PDO111 vs. PAO1 & 10 & Decrease $<0.0001$ & Decrease $<0.0001$ & Increase 0.0027 & NS & Increase $<0.0001$ \\
\hline PDO100 vs. PAO1 & 10 & Decrease 0.0026 & Decrease 0.0120 & Increase 0.0020 & NS & Increase 0.0175 \\
\hline PW2798 vs. PAO1 & 10 & NS & NS & NS & NS & NS \\
\hline
\end{tabular}

${ }^{a}$ All strains carry pMRP9-1 and were grown under $10 \% \mathrm{EO}_{2}$ without shaking.

${ }^{b}$ See Table 1 for description of parameters.

${ }^{c} \mathrm{NS}$, no significant difference.

${ }^{d}$ Significant change with $P$ value indicated below direction of change. 
by PAO1 with those formed by these same QS mutants. The mutants were transformed with PMRP9-1 and the development of the BLS by the transformants was examined under $10 \% \mathrm{EO}_{2}$ for $3 \mathrm{~d}$ at $37^{\circ} \mathrm{C}$.

The las mutants PAO-R1 ( $\Delta l a s R)$ and PAO-JP1 (DlasI) produced BLS that visually and architecturally resembled each other (Figure 8A, B). With respect to the five tested parameters, BLS produced by PAO-JP1 were not significantly different from those BLS produced by PAO1 (Tables 3 and 4). The mean thickness of BLS produced by PAO-R1 was significantly higher than that of PAO1 BLS while the roughness coefficient was significantly lower (Tables 3 and 4). The pqs mutant PW728::pqsA-lacZ produced BLS that were not significantly different from PAO1 BLS (Figure 8; Tables 3 and 4). The biovolume and mean thickness of BLS produced by either the rhlI mutant (PDO100) or rhlR (PDO111) were significantly less than those produced by PAO1 (Figure 8; Tables 3 and 4). In contrast the values of the roughness coefficient and the surface to biovolume ratio were significantly higher than those for PAO1 BLS (Figure 8; Table 3 and 4). These results suggest that among all three QS systems, rhlI and $r h l R$ have a major impact on the development of BLS in ASM+ by PAO1.

\section{S. aureus develops BLS under $20 \% \mathrm{EO}_{2}$ but not $10 \% \mathrm{EO}_{2}$}

$S$. aureus is one of the first microorganisms that colonize and grow within the thick mucus in the lung alveoli of CF patients [8]. Thus, we determined whether $S$. aureus would develop BLS in ASM+ under $20 \%$ or $10 \% \mathrm{EO}_{2}$. The $S$. aureus strain AH133 which carries the GFP plasmid pCM11, was grown for $3 \mathrm{~d}$ at $37^{\circ} \mathrm{C}$. Under $20 \%$ $\mathrm{EO}_{2}, \mathrm{AH} 133$ produced a well developed BLS within the entire gelatinous mass (Figure 9). However, under 10\% $\mathrm{EO}_{2}$, the structures were far less developed with individual cells/small microcolonies scattered within the gelatinous mass (Figure 9). Compared to BLS produced under 20\% $\mathrm{EO}_{2}$, total biovolume, mean thickness, and surface area of BLS produced under $10 \% \mathrm{EO}_{2}$ were significantly reduced $(P<0.0001$ for each value) (Table 5$)$. In contrast, the roughness coefficient and surface to biovolume ratio values were significantly increased $(P<0.0001$ for each value) (Table 5$)$. This suggests that unlike $P$. aeruginosa, $S$. aureus produces more developed BLS under $20 \% \mathrm{EO}_{2}$ rather than under $10 \% \mathrm{EO}_{2}$.

\section{P. aeruginosa eliminates BLS established by $S$. aureus within ASM+}

The lungs of CF patients are colonized with a variety of pathogens, including $S$. aureus, $P$. aeruginosa, and $K$. pneumoniae, over the course of time [1]. However, as the disease progresses, the predominate pathogen within the CF infected lung is $P$. aeruginosa $[1,8]$. Previous studies showed that QS-controlled extracellular factors produced by $P$. aeruginosa, including quinoline molecules and LasA, inhibited the planktonic growth of S. aureus and S. epidermidis [31,32]. Additionally, recent studies showed that the $P$. aeruginosa extracellular polysaccharide as well as the organic compound cis-2-decenoic acid disrupted established biofilms produced by Gram-positive bacteria [33]. Therefore, we first determined if PAO1 inhibits the growth of the $S$. aureus strain AH133 in ASM+. We co-inoculated ASM+ with approximately $1 \times 10^{7} \mathrm{CFU} / \mathrm{ml}$ each of PAO1 and AH133 and incubated the culture for $48 \mathrm{~h}$ at $37^{\circ} \mathrm{C}$ under $20 \% \mathrm{EO}_{2}$. After $48 \mathrm{~h}$, about 1 x $10^{9} \mathrm{CFU} / \mathrm{ml}$ of PAO1 was recovered from the gelatinous ASM+ mass, but no CFU of AH133 (Figure 10A). We obtained similar results when we repeated the experiments using TSBDC, a growth medium that supports planktonic growth of both organisms (Figure 10B). These results suggest that similar to other previous observations, $P$. aeruginosa eliminates $S$. aureus, when the two are grown together at the same time.

To simulate the scenario in which $S$. aureus colonizes the CF lung first and $P$. aeruginosa follows, we then examined the effect of PAO1 on partially developed (8 h) AH133 BLS. As AH133 expresses GFP, we transformed PAO1 with pMP7605, a plasmid from which RFP is expressed constitutively [34], to allow visualization of each strain within the BLS. Individually, the strains produced well developed BLS in ASM+ (Figures 2, 10A). At $8 \mathrm{~h}$ post inoculation, AH133 formed a defined structure (Figure 11A). We then added PAO1/ pMP7605 (at a starting density similar to that used to initiate the AH133 culture) and continued incubation for $56 \mathrm{~h}$. The cultures were analyzed at 8- and 16-h intervals to $64 \mathrm{~h}$ for the AH133 alone and $56 \mathrm{~h}$ post addition of PAO1/pMP7605 for changes in the BLS produced by AH133 and the development of any PAO1 BLS (Figure 11A, B). At 16 and $24 \mathrm{~h}$ post-initiation, AH133 produced well-developed mature BLS (Figure 11A). The AH133 BLS changed in appearance over the rest of the time course, but did not disappear (Figure 11A). In contrast, in the dual culture, the AH133 structure was considerably reduced at the corresponding time points (Figure 11B). By $32 \mathrm{~h}$ only remnants of the AH133 BLS remained, and by 40-56 h, the AH133 BLS appeared to be completely replaced by well-developed PAO1 BLS (Figure 11B). The regression of AH133 structure appears to be due to the expansion of the PAO1 structure at 8 , 16, and $32 \mathrm{~h}$ post-initiation (Figure $11 \mathrm{~B}$ ).

This observed phenomenon could be due to the dispersion of the AH133 BLS or a bactericidal effect of PAO1 on AH133. Therefore, at each time point, the gelatinous masses containing AH133 alone or AH133 plus PAO1 were vortexed, serially diluted, and the $\mathrm{CFU} / \mathrm{ml}$ determined. Aliquots of each dilution were spotted on 


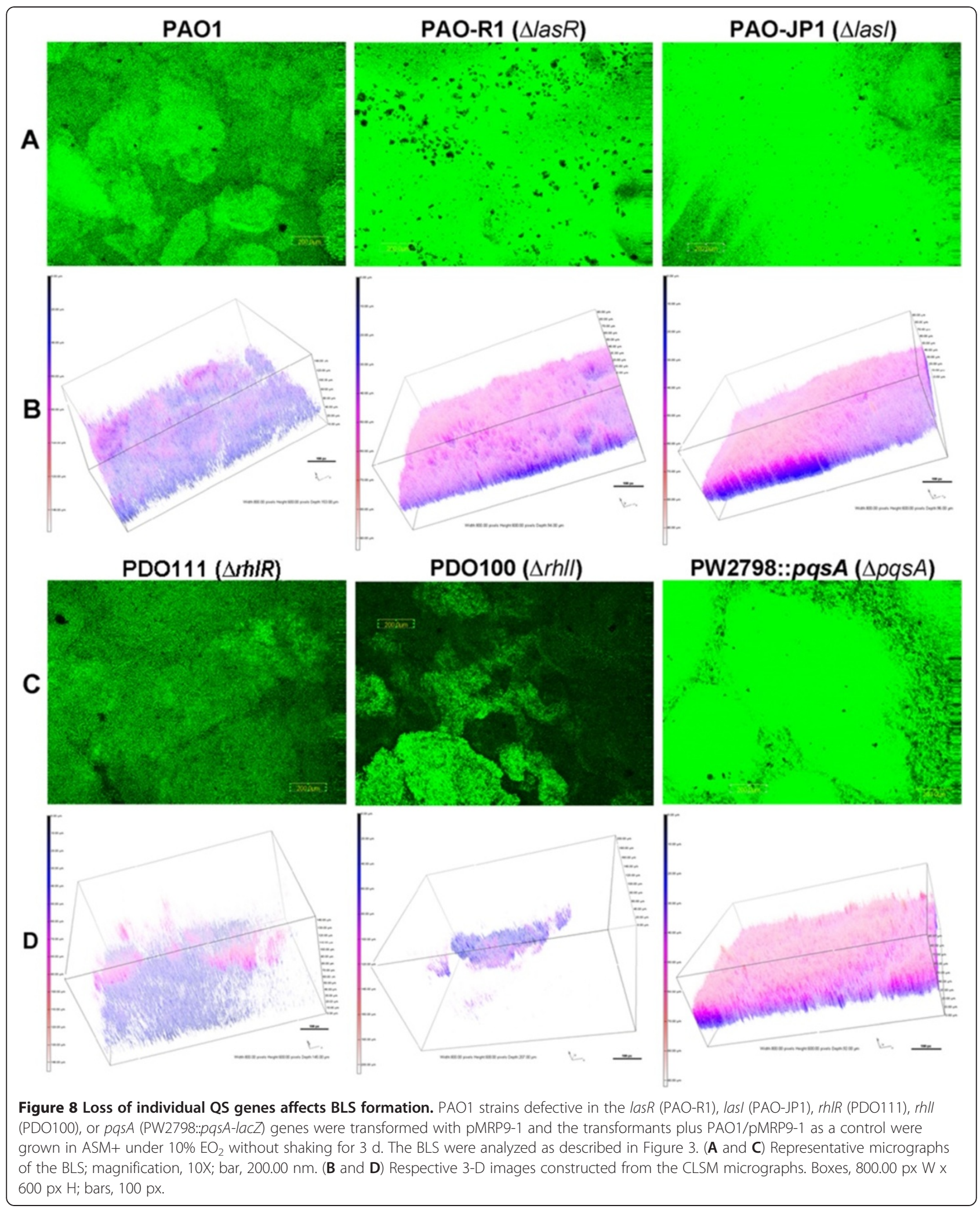

Pseudomonas isolation agar for $P$. aeruginosa and mannitol salt agar for $S$. aureus. At all tested time points, the $\mathrm{CFU} / \mathrm{ml}$ of the single AH133 biofilm was similar (about
$1 \times 10^{7}$ ) (Figure $11 \mathrm{C}$, white bars). However, the CFU/ml of AH133 within the mixed BLS was visibly reduced $8 \mathrm{~h}$ after addition of PAO1 and significantly reduced at 40 


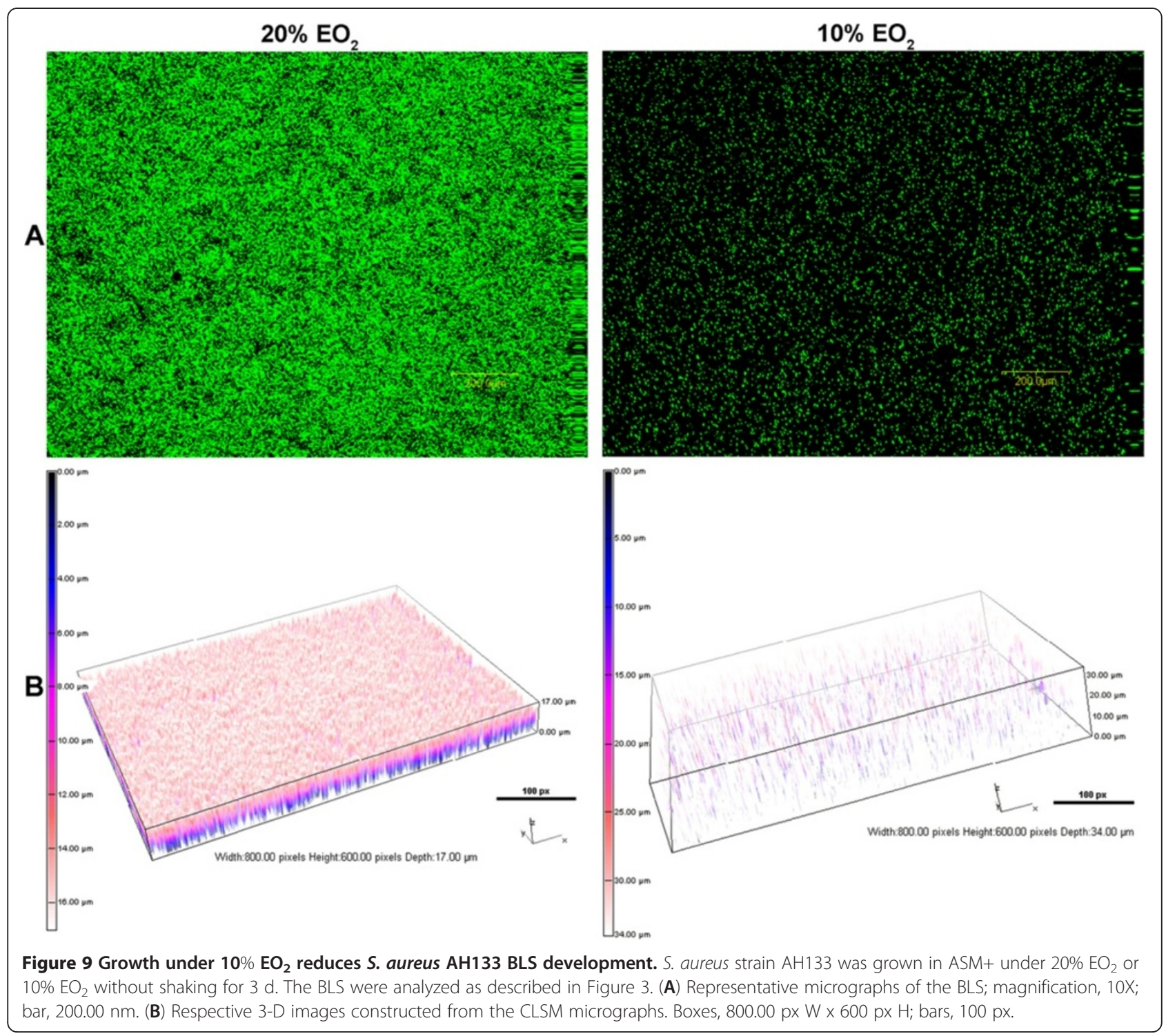

and $56 \mathrm{~h}$, with no CFU of AH133 recovered $56 \mathrm{~h}$ post addition of PAO1 (Figure 11C, green bars). In contrast, the $\mathrm{CFU} / \mathrm{ml}$ of PAO1/pMP7605 within the mixed BLS dropped between 8 and 16 h post biofilm initiation but did not change significantly after $16 \mathrm{~h}$ (Figure $11 \mathrm{C}$, red bars). These results suggest that PAO1 exerts a bactericidal effect, and that the development of the $P$. aeruginosa BLS in the co-culture proceeded at the expense of the S. aureus BLS.

\section{Discussion}

CF sputum is a highly viscous secretion in which PAO1 grows readily. PAO1 forms conventional biofilms on abiotic surfaces $[13,19,35]$, but it develops macrocolonies, tight aggregates consisting of numerous microcolonies, in ASM and the CF lung [16,21]. While PAO1 formed a typical flat undifferentiated biofilm that completely covered the substratum with a homogenous distribution of the biovolume in a continuous flow-through system, it

Table 5 Effect of oxygen on Staphylococcus aureus AH133 BLS ${ }^{a}$

\begin{tabular}{|c|c|c|c|c|c|c|}
\hline $\mathrm{EO}_{2}$ & $\begin{array}{c}\text { Image } \\
\text { stacks }(\#)^{b}\end{array}$ & $\begin{array}{l}\text { Total biovolume } \\
\left(\mu \mathrm{m}^{3} / \mu \mathrm{m}^{2}\right)^{b}\end{array}$ & $\begin{array}{l}\text { Mean thickness } \\
\qquad(\mu \mathrm{m})^{b}\end{array}$ & $\begin{array}{l}\text { Roughness } \\
\text { coefficient }^{b}\end{array}$ & $\begin{array}{c}\text { Total surface } \\
\text { area } \times 10^{7}\left(\mu \mathrm{m}^{2}\right)^{b}\end{array}$ & $\begin{array}{l}\text { Surface to volume } \\
\text { ratio }\left(\mu \mathrm{m}^{2} / \mu \mathrm{m}^{3}\right)^{b}\end{array}$ \\
\hline $20 \%$ & 9 & $7.00 \pm 0.46$ & $7.57 \pm 0.50$ & $0.58 \pm 0.17$ & $0.76 \pm 0.12$ & $0.57 \pm 0.09$ \\
\hline $10 \%$ & 9 & $0.22 \pm 0.03$ & $0.27 \pm 0.04$ & $1.90 \pm 0.02$ & $0.07 \pm 0.00$ & $1.59 \pm 0.01$ \\
\hline
\end{tabular}

\footnotetext{
${ }^{a}$ Strains were grown for $3 \mathrm{~d}$ without shaking.
}

${ }^{b}$ See Table 1 for description of parameters. 

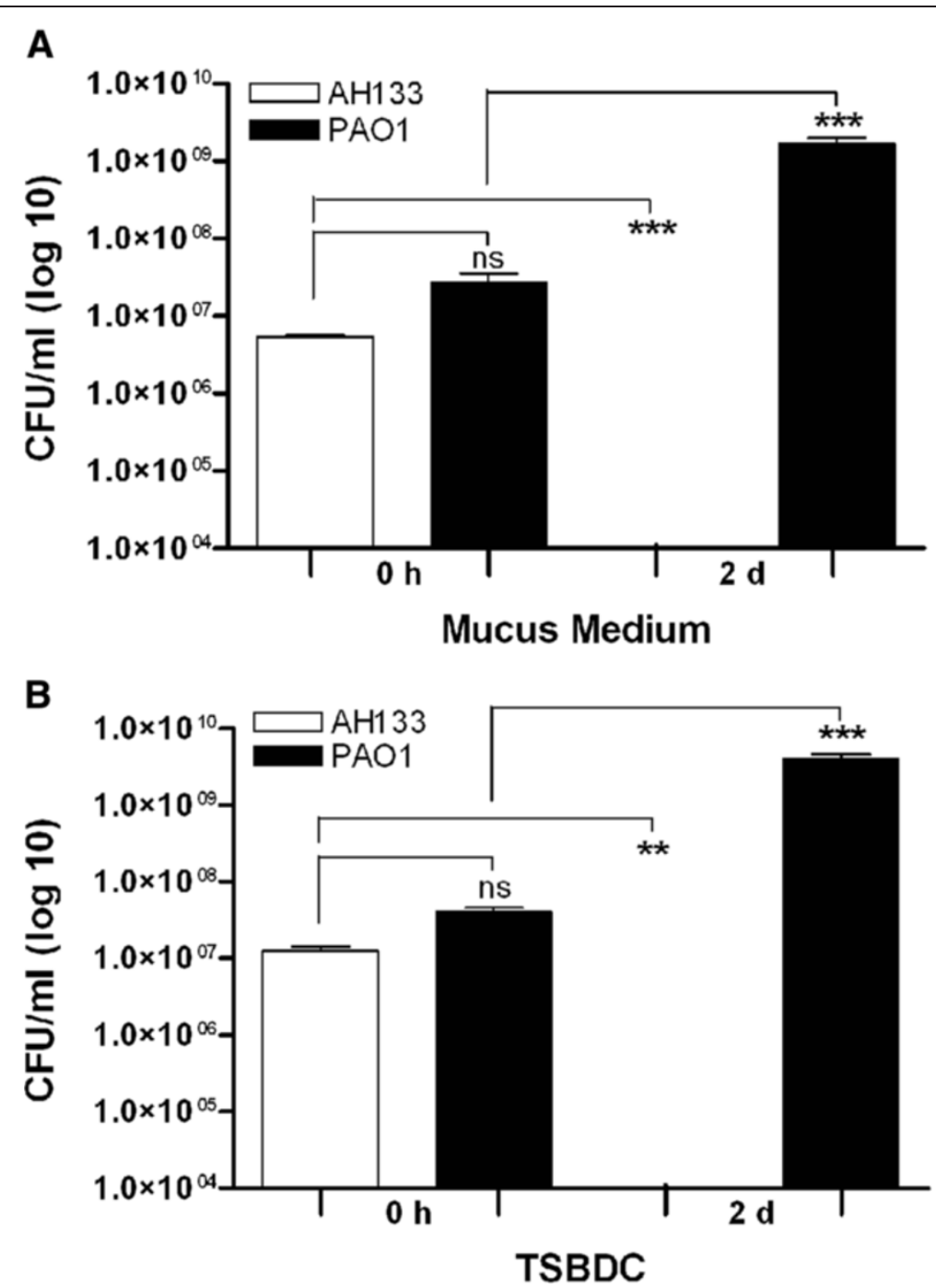

Figure 10 PAO1 inhibits AH133 in co-culture. Overnight LB cultures of AH133 and PAO1/pMRP9-1 were pelleted, washed, and resuspended in PBS. Resuspended cells of each species were inoculated into ASM+ (A) or TSBDC (B) at an initial $\mathrm{OD}_{600}$ of approximately 0.015 . The CFU/ml of each species was determined at the time of inoculation (0-time) and after $48 \mathrm{~h}$ of growth using selective media (Methods). The graphs show $\mathrm{CFU} / \mathrm{ml}$ obtained from BLS in ASM+ (A) and planktonic growth in TSBDC (B). Values represent the means of at least three independent experiments \pm SEM.

grew almost exclusively as discrete microcolonies that eventually formed a mature biofilm on a mucin-covered glass surface [19]. Based on these results, Landry et al. suggested that mucin interacts with specific PAO1 adhesins thereby immobilizing the bacteria onto the glass surface [19]. In our analysis, the observed BLS developed exclusively within the gelatinous mass formed by ASM+ and not on the surface of the well (Figure 1). It is likely that through the initial interaction of these putative adhesins, individual PAO1 bacteria adhere to the mucin glycoprotein forming the nuclei of the microcolonies and leaving no bacteria to adhere to the plastic surface. Individual nuclei would then recruit more PAO1 bacteria, possibly through additional inter-bacterial and glycoprotein-bacterial interactions, growing into welldefined BLS observed over time (Figure 2).

Based on the work of Ghani \& Soothill [15] and Sriramulu et al. [16], we utilized 0.5\% mucin (1X) in our ASM+. But more recently, Henke et al. [36], showed that the concentrations of MUC5AC and MUC5B, the principal gelforming mucins, are decreased in airway secretions from CF patients with stable disease and greatly increased during pulmonary exacerbations (by $89 \%$ and $908 \%$, respectively). When we reduced the mucin concentration of ASM+ by $50 \%(0.5 \mathrm{X})$, the gelatinous mass still formed in the well, possibly through the contribution of other ASM+ components (DNA and lecithin) that add to the viscosity. However, the typical multilayered BLS was eliminated and 


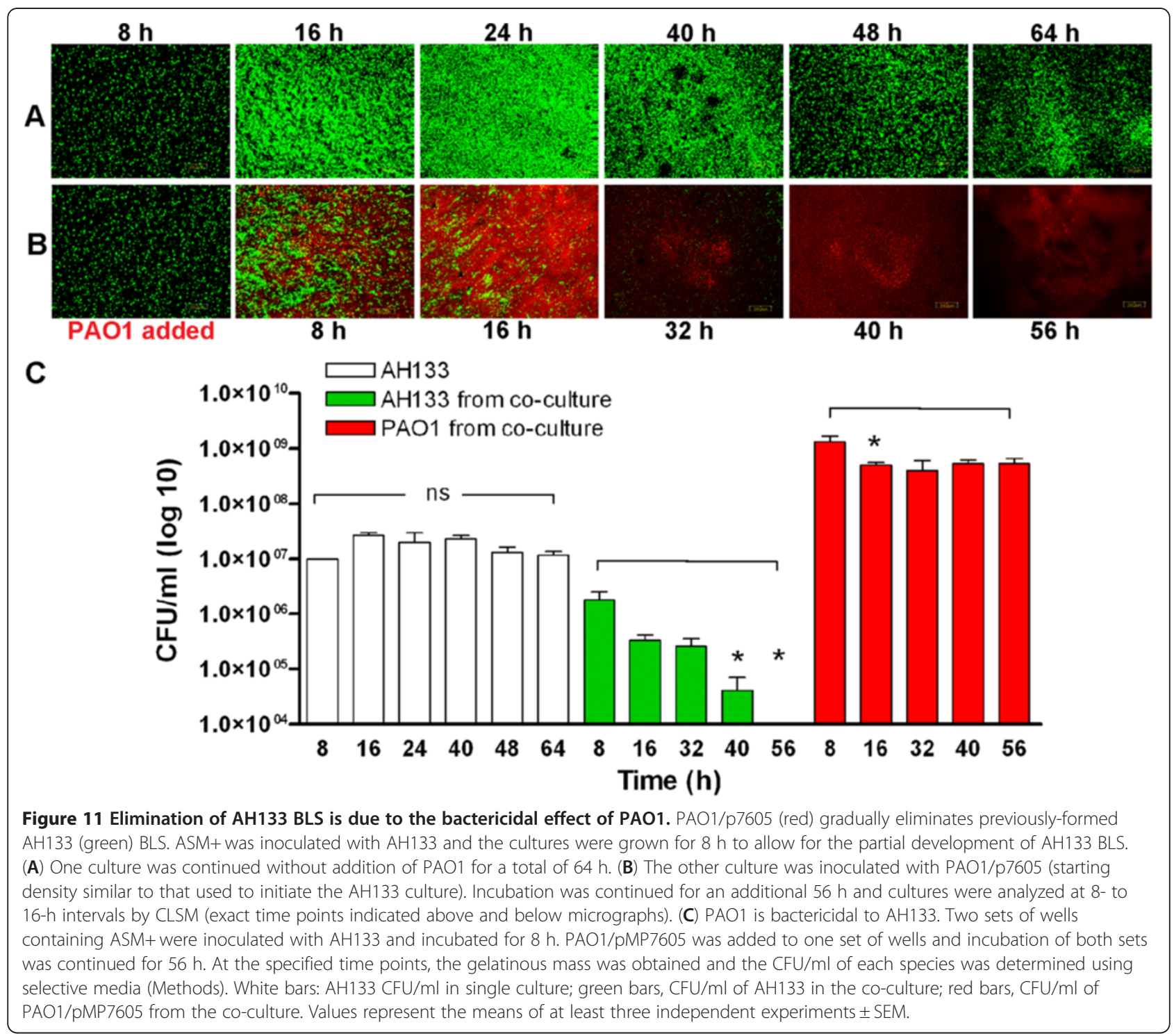

replaced with a structure that appears to consist of small microcolonies amid individual cells and tiny cell clusters distributed throughout most of the gelatinous mass (Figure 4A, B). Surprisingly, the effect of increasing the concentration of mucin to $2 \mathrm{X}$ on the development of BLS was similar to that induced by reducing the mucin concentration. Rather than the distinct highly structured BLS architecture, PAO1 produced small microcolonies distributed throughout the ASM+ (Figure 4C). At this time, we do not know if the increase in the availability of mucin glycoprotein interferes with the development of microcolonies that coalesce to form the well-developed BLS.

One of the hallmarks of the CF syndrome is the overproduction of mucin within the lung alveoli [1,3,7]. Yet during $P$. aeruginosa infection of the CF lung alveoli, the level of mucin may vary [36]. P. aeruginosa LPS induces the production of reactive oxygen intermediates, which cause release of transforming growth factor $\alpha$; TGF- $\alpha$ then up-regulates the expression of MUC-5 AC thereby causing excessive mucin production[37-39]. However, P. aeruginosa produces other factors that may reduce the amount of mucus within its immediate vicinity; alveolar mucin is degraded by $P$. aeruginosa extracellular serine proteases such as LasB [40]. Ultimately, the interaction of all these factors would produce a net mucin concentration suitable for the full development of the BLS, while any imbalance in the production of these factors that reduces or increases mucin concentration would prevent the establishment of the BLS. Alternatively, BLS may form in the initial stages of $P$. aeruginosa infection in the CF lung. Treatment that reduces the amount of mucin present would disperse the bacteria making them more susceptible to antibacterial treatment (stable disease). Alternatively, mucin may reduce the chances of forming new BLS. 
Extracellular DNA is another contributor to the viscosity of CF sputum $[15,16]$. Within the CF lung, there are several sources for this extracellular DNA - dead host immune cells, lysed bacteria, QS-regulated release of $P$. aeruginosa DNA, and outer membrane vesicles that contain DNA [41,42]. Like mucin, DNA contributes to biofilm formation as well; a similar biofilm was detected on a glass surface coated with DNA [41]. Previous studies using other biofilm development media, such as LB or minimal medium, indicated that extracellular DNA is critical for the initial establishment of $P$. aeruginosa biofilms [42]. The levels of extracellular DNA also vary within CF sputum, ranging from 0.3 to $9.5 \mathrm{mg} / \mathrm{ml}$ in one study of 167 CF sputum samples [43]. Variations in the level of extracellular DNA in ASM+ affected the development of BLS much more dramatically than variations in the level of mucin. In ASM+ with 0.5X DNA ( $2 \mathrm{mg} / \mathrm{ml})$, a well developed BLS was visible (Figure $5 \mathrm{~B}$ ), but the biovolume and total surface area occupied were considerably less (Table 1 and 2). When the amount of DNA was increased to $1.5 \mathrm{X}(6 \mathrm{mg} / \mathrm{ml})$, PAO1 did not produce detectable structures; rather, the gelatinous mass formed by the ASM+ contained scattered individual cells (Figure 4C). However, at this time it is not clear how an increase in the external DNA reduces the number of BLS within the gelatinous mass of ASM+.

Within the lung of CF patients and during other chronic lung infections, $P$. aeruginosa survives under microaerobic $\left(10 \% \mathrm{EO}_{2}\right)$ to anaerobic $\left(0 \% \mathrm{EO}_{2}\right)$ conditions. A steep oxygen gradient exists within the $P$. aeruginosa infected alveolar mucus [5,21]. Within the mucus, $P$. aeruginosa secretes compounds that lower the oxygen transfer rate generating optimum conditions for microaerobic growth $[22,44]$. We showed previously that lower oxygen tension also influences the expression of $P$. aeruginosa virulence genes [45]. Compared with aerobic conditions, the expression of pyoverdine genes was reduced under microaerobic conditions; in contrast, the expression of the exotoxin A gene, tox $A$ was increased [45]. Compared with $20 \% \mathrm{EO}_{2}$ and $0 \% \mathrm{EO}_{2}$, microaerobic $\left(10 \% \mathrm{EO}_{2}\right)$ conditions are optimal for the development of $P$. aeruginosa BLS in ASM+. BLS developed under $10 \% \mathrm{EO}_{2}$ had a greater mean thickness and a larger biovolume than those developed under either $20 \%$ or $0 \% \mathrm{EO}_{2}$ (Figure 6, Table 1 and 2). In the absence of $\mathrm{EO}_{2}$, PAO1 required 6 days to develop rudimentary BLS (Figure 6C) indicating that a low level of oxygen is essential for the full development of these structures.

Depending on conditions under which the biofilms were developed (medium, the biofilm development system, and the biofilm substrate), previous studies indicated the involvement of the QS systems in the development of $P$. aeruginosa biofilm [29,30,35,46]. In those studies, the deficiency in biofilm development was associated with either a lasI or rhlI mutation. We tested mutants defective in all three known $P$. aeruginosa QS

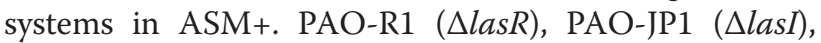
and PW2798::pqsA-lacZ ( $\Delta p q s A)$ produced BLS that were visually and architecturally similar to each (Figure 8). In contrast, PDO111 ( $\Delta r h l R)$ BLS were visually, architecturally, and structurally dissimilar to PAO1 BLS, in that they had a smaller biovolume and mean thickness (Figure 8, Tables 3 and 4). The loss of rhl (PDO100) had the most profound effect on the BLS produced by PAO1 in ASM+. Both PDO100 ( $\Delta r h l I)$ and PDO111 $(\Delta r h l R)$ produced BLS that were significantly smaller (biovolume, mean thickness) than PAO1 BLS (Figure 8, Tables 3 and 4). However, BLS produced by these two strains were more heterogeneous than PAO1 BLS (a significant increase in roughness coefficient) (Figure 8, Tables 3 and 4). Additionally, more regions of the PDO100 and PDO111 BLS were exposed to nutrients than PAO1 BLS (a significantly higher surface to biovolume values) (Figure 8 , Tables 3 and 4). Our results suggest that the production and maturation of the fully-developed complex BLS requires a potential $P$. aeruginosa factor that is stringently controlled by the $r h l$ and not the las or the pqs systems. Among the $P$. aeruginosa factors that are stringently controlled by the $r h l$ system are the rhamnolipid biosurfactants $[47,48]$. The rhamnolipids encoded by the $\operatorname{rhl} A B$ operon contribute to biofilm development in $P$. aeruginosa through multiple mechanisms including maintaining open channels by affecting cell-to-cell interaction [28], promoting microcolony formation in the initial stages of biofilm development [49], and dispersing cells from the mature biofilms [50]. Analysis of PAO $\Delta r h l A$ and/or PAO $\Delta r h l B$ mutants in $\mathrm{ASM}+$ should allow us to determine if rhamnolipid plays a role in the development of the BLS. Interestingly, PA103, which is known to have a deletion in lasR [51], produced BLS with reduced biovolume and mean thickness (compared with those produced by PAO1 or PAO-R1) (Figure 7, Tables 3 and 4). This suggests that the observed differences between the BLS produced by PAO1 and PA103 are not due to the loss of the lasR gene in PA103. CI-4, a clinical isolate obtained from a patient who had been continuously infected with $P$. aeruginosa for 30 days, has deletions in both lasR and rhlR [27]. This strain produced BLS that had less biovolume, mean thickness and covered less total surface area that PAO1; visually, the BLS were also unique in appearance among all the QS mutants, numerous small microcolonies distributed throughout the medium (Figure 7, Tables 3 and 4). This suggests that there is a complex interaction among the QS systems in controlling BLS production within ASM+.

Using ASM+, which has the same components as our ASM+, Sriramula et al. [16] examined the growth of PAO1, 
$\mathrm{PAO} \Delta l a s R$, and PAO $\Delta r h l R$. Both PAO1 and PAO $\Delta r h l R$ formed macroscopically visible clumps or aggregates, which they termed tight microcolonies, that could not be disturbed even with vigorous pipetting [16]. In contrast, PAO$\triangle l a s R$ failed to develop these tight microcolonies [16]. In our study, neither PAO1, nor any other tested strain produced macroscopically visible structures. In part, this is due to the turbidity of ASM+. Similar to the tight microcolonies described by Sriramula et al. [16], the BLS we observed in our ASM+ did not attach to a surface. The BLS are adherent when fully-developed, but cells within the BLS can be dispersed by vortexing. Differences between the two studies, despite the similarity in the growth medium, are most likely due to differences in other growth conditions. While Sriramula et al. [16], grew their cultures under $20 \% \mathrm{EO}_{2}$ with shaking, we grew our cultures under static conditions regardless of the $\mathrm{EO}_{2}$ concentration. Given these differences, it is not practical to directly compare the bacterial structures observed in the two studies with respect to the role of the QS systems in their formation.

Biofilms at different infection sites often consist of multiple species of bacterial pathogens [52,53]. These bacterial species may either compete with each other or support each other's growth. Qin et al. [54] previously showed that $P$. aeruginosa inhibited the planktonic growth of Staphylococcus epidermidis through a QSrelated mechanism. Additionally, using the static chamber cultivation system (microtiter plate assay), they demonstrated that $P$. aeruginosa extracellular polysaccharide disrupted an already established S. epidermidis biofilm [54]. Disruption of these biofilms, however, does not occur through the bactericidal effect observed with the planktonic cells; instead the bacteria within the biofilm were dispersed alive [54]. When we co-cultured $P$. aeruginosa and $S$. aureus statically under $20 \% \mathrm{EO}_{2}$ in TSBDC or ASM+, P. aeruginosa eliminated S. aureus by day 2 (Figure 10). Furthermore, and similar to the findings by Qin et al. with S. epidermidis [54], the addition of $P$. aeruginosa to $S$. aureus BLS established in ASM+ disrupted the $S$. aureus BLS (11a, b). However, P. aeruginosa disrupted the $S$. aureus BLS through an bactericidal effect rather than dispersion. By 56-h post addition of PAO1, no CFU of AH133 were recovered (Figure 11C), although it is remotely possible that our failure to detect $S$. aureus is due to their existence in a viable but nonculturable state. This effect is similar to the clinical observations of CF lung infections where $S$. aureus, an early colonizer, is gradually replaced by $P$. aeruginosa. The nature of the PAO1 bactericidal factor that eliminates the $S$. aureus BLS is under investigation.

\section{Conclusions}

In this study, we have demonstrated that thick, viscous $\mathrm{ASM}+$ containing mucin and extracellular DNA and incubated under static conditions with lowered oxygen tension $\left(10 \% \mathrm{EO}_{2}\right)$ - constituents and conditions similar to those within the lung alveoli of CF patients - induces the formation of biofilm-like structures by $P$. aeruginosa and $S$. aureus, two of the pathogens most commonly seen in the infected lungs of these patients. The BLS are not attached to the surface, but form within the medium as has been reported for the development of macrocolonies within the mucus in $\mathrm{CF}$ lungs. Thus, ASM+ represents an in vitro medium in which the effect of changing levels of substances produced by the host and the bacteria can be analyzed to determine the effect on such structures and on the susceptibility of the bacteria within the BLS to various treatments.

\section{Methods}

\section{Bacterial strains, plasmids, and media}

Bacterial strains and plasmids utilized in this study are described in Table 6. Strains were routinely grown in Luria Bertani (LB) broth under shaking conditions at $37^{\circ} \mathrm{C}$. To analyze the development of biofilm-like structures, bacterial strains were grown in the previously described ASM+ [16]. To attain consistency from batch to batch of medium ASM+ was made in a quantity sufficient for each planned set of experiments, a stringent method of preparing the medium was used. The components were added into sterile water in exact order with vigorous vortexing for $10-30$ seconds after each addition: mucin (Sigma-Aldrich, St. Louis, MO), 0.5\% (w/v); unsheared salmon sperm DNA (Sigma-Aldrich), $0.4 \%(\mathrm{w} / \mathrm{v}) ; \mathrm{NaCl}, 0.5 \%(\mathrm{w} / \mathrm{v}) ; \mathrm{KCl}, 0.2 \%(\mathrm{w} / \mathrm{v}) ;$ casamino acids (Amresco, Solon, $\mathrm{OH}), 0.5 \%(\mathrm{w} / \mathrm{v})$; egg yolk emulsion (source of lecithin; sterile; Remel, Lenexa, KS), $0.25 \%(\mathrm{v} / \mathrm{v})$; diethylene triamine pentaacetic acid $(1 \mathrm{mg} /$ $\mathrm{ml}$ stock in $1 \mathrm{M} \mathrm{NaOH}$; sterile; Sigma), $0.0005 \%(\mathrm{w} / \mathrm{v})$. Finally, the $\mathrm{pH}$ was adjusted to 6.8. Antibiotics were then added to maintain sterility and for maintenance of plasmids: $300 \mu \mathrm{g}$ carbenicillin/ml and/or $50 \mu \mathrm{g}$ tetracycline/ml for $P$. aeruginosa; $10 \mu \mathrm{g}$ erythromycin $/ \mathrm{ml}$ for $S$. aureus. The completed medium was then vortexed for 2 minutes and again prior to pipetting. To induce biofilm formation on the substrate surface, we used trypticase soy broth dialysate (TSBDC) to which glycerol $(1 \% \mathrm{v} / \mathrm{v})$ and monosodium glutamate $(0.5 \mathrm{M})$ were added [55].

To allow visualization of the bacteria, all $P$. aeruginosa strains were transformed by electroporation [63] with pMRP9-1 from which the gene for green fluorescent protein (GFP) is constitutively expressed [56]. To visualize PAO1 grown together with AH133, PAO1 was transformed with pMP7605 in which the mCherry gene that codes for red fluorescent protein (RFP) is expressed from the tac promoter [34]. The S. aureus strain AH133 
Table 6 Strains and plasmids used in this study

\begin{tabular}{|c|c|c|}
\hline Strain & Description & Source \\
\hline \multicolumn{3}{|l|}{ Plasmids } \\
\hline pCM11 & $\begin{array}{l}\text { Plasmid stable in S. aureus that constitutively } \\
\text { expresses green fluorescent protein (GFP); Em }{ }^{r}\end{array}$ & $\begin{array}{l}\text { Alexander Horswill, personal } \\
\text { communication }\end{array}$ \\
\hline pMRP9-1 & pUCP-18 cloning vector carrying a GFP cassette; $\mathrm{Cb}^{r}$ & {$[56]$} \\
\hline pMP7605 & $\begin{array}{l}\text { pBBR1MCS- } 5 \text { cloning vector carrying the mCherry } \\
\text { gene under the control of the tac promoter; } C b^{r}\end{array}$ & [34] \\
\hline \multicolumn{3}{|c|}{ Pseudomonas aeruginosa } \\
\hline PA103 & Human isolate & [24] \\
\hline PAK & Prototroph; human isolate & [57] \\
\hline PAO1 & Prototroph; human isolate & [58] \\
\hline PAO-R1 & $\Delta$ las $R$ derivative of $\mathrm{PAO} 1 ; \mathrm{TC}^{r}$ & [51] \\
\hline PAO-JP1 & $\Delta$ las/ derivative of $\mathrm{PAO} 1 ; \mathrm{TC}^{\mathrm{r}}$ & [59] \\
\hline PDO111 & rhIR::Tn501 derivative of $\mathrm{PAO} 1 ; \mathrm{Hg}^{\mathrm{r}}$ & {$[60]$} \\
\hline PDO100 & $\Delta$ rhll::Tn501 derivative of $\mathrm{PAO} 1 ; \mathrm{Hg}^{\mathrm{r}}$ & [60] \\
\hline PW2798::pqsA-lacZ & pqsA-H05::ISlacZ/hah derivative of PAO1; $\mathrm{Tc}^{r}$ & $\begin{array}{l}\text { [61]; University of Washington } \\
\text { Genome Center }\end{array}$ \\
\hline $\mathrm{Cl}-4$ & $\begin{array}{l}\text { Human isolate from chronic lower respiratory } \\
\text { infection; } \Delta \text { las } R, \Delta r h l R\end{array}$ & [27] \\
\hline \multicolumn{3}{|c|}{ Staphylococcus aureus } \\
\hline $\mathrm{AH} 133$ & RN4220 carrying pCM11; Em ${ }^{r}$ & $\begin{array}{l}\text { [62]; Alexander Horswill, personal } \\
\text { communication }\end{array}$ \\
\hline
\end{tabular}

Em, erythromycin; ${ }^{r}$, resistant; $\mathrm{Cb}$, carbenicillin; $\mathrm{Hg}$, mercury; $\mathrm{Tc}$, tetracycline.

carries the constitutive GFP plasmid pCM11 (AR Horswill, personal communication).

\section{Static microtiter plate culture system for development of the BLS}

Bacteria were grown in a static microtiter plate culture system using sterile 24-well polystyrene plates (Falcon; BD, Franklin Lakes, NJ) [64,65]. Tested strains were grown overnight in LB broth. Cells were pelleted, washed, and resuspended in PBS. For analysis of the BLS formed by individual bacterial species, resuspended cells were inoculated in $\mathrm{ASM}+$ to an initial $\mathrm{OD}_{600}$ of $0.02-0.03$ and dispensed into the plate wells in $1 \mathrm{ml}$ aliquots. For the analysis of BLS produced by two bacterial species, individual species were prepared and inoculated at an initial $\mathrm{OD}_{600}$ of 0.015 . The plates were incubated at $37^{\circ} \mathrm{C}$ in static (nonshaking) conditions under environmental oxygen $\left(\mathrm{EO}_{2}\right)$ concentration of $20 \%$ (aerobic), $10 \%$ (microaerobic), or $0 \%$ (anaerobic). Individual GasPak jars with Campy Pak Plus envelopes (BD) or GasPak EZ Anaerobic Pouches (BD) were used to generate the microaerobic and anaerobic $\mathrm{EO}_{2}$ conditions, respectively.

\section{Visualization of the BLS}

This was done using confocal laser scanning microscopy (CLSM) [35,64]. The BLS were visualized within the wells of the microtiter plates using an Olympus IX71 Fluoview 300 confocal laser scanning microscope (Olympus America, Melville, NY). All images were obtained through a 203/0.40 Ph1 NA objective utilizing a green helium laser (546 nm) or argon laser (510-530 nm). Three-dimensional image reconstructions were performed using NIS-Elements 2.2 (Nikon Instruments, Melville, NY) to visualize the architecture of the BLS. All instrument settings were consistent for each individual experimental parameter tested.

\section{Quantitative structural analysis of the BLS}

The number of image stacks obtained from the BLS was based on the greatest depth of the structures formed under the test conditions and was the same for all strains/conditions within an experiment (See Tables 1, 2, $3,4)$. Each experiment was done in duplicate. Two 10image stacks were obtained from random positions within each BLS (total 40-image stacks for each strain and/or condition). The 40-image stacks were analyzed using the COMSTAT program [20] for structural features of the BLS: biovolume, estimates the biomass of the BLS; mean thickness, a measure of spatial size of the BLS; roughness coefficient, a measure of how much the thickness of the BLS varies, or the heterogeneity of the BLS; total surface area, space occupied in each image stack; and surface to biovolume ratio, estimates the portion of the BLS exposed 
to nutrients (biovolume divided by the surface area of the substratum). Values represent the mean \pm SEM.

\section{Quantification of the bacteria within the BLS}

The highly viscous ASM+ forms a gelatinous mass in which the bacteria grow. Therefore, at the indicated time points, the mass from each well was transferred to a $1.5 \mathrm{ml}$ microcentrifuge tube and vigorously vortexed to suspend the bacteria. The bacterial suspension was then serially diluted tenfold in PBS and $10 \mu \mathrm{l}$ aliquots of each dilution were spotted on LB agar. For dual species experiments, the aliquots were spotted on Pseudomonas isolation agar (BD) to select for $P$. aeruginosa and mannitol salt agar (BD) to select for $S$. aureus. The plates were incubated at $37^{\circ} \mathrm{C}$ for $16 \mathrm{~h}$ and the colonies of microorganisms (CFU) were counted. The $\mathrm{CFU} / \mathrm{ml}$ was determined using the following formula: CFU counted $\mathrm{x}$ dilution factor $\mathrm{x} 100$.

\section{Statistical analyses}

Statistical analyses of the results were done using GraphPad InStat 3.06 (GraphPad Software, San Diego, CA). One-way ANOVA with the Tukey-Kramer multiple comparisons post-test was used to determine significant differences over time and among treatments. The $t$-test was used to compare two strains or two treatments.

\section{Authors' contributions}

$\mathrm{CH}$ designed portions of the study, conducted all experiments, and wrote the manuscript. ANH coordinated the project, designed portions of the study, and helped draft and revise the manuscript. JACH analyzed and interpreted data and critically revised the manuscript. All authors have read and approved the final manuscript.

\section{Acknowledgements}

We thank Guido V. Bloemberg and Ellen L. Langendijk (pMP7605), Alexander R. Horswill (AH133/pCM11), Barbara H. Iglewski (PAO1, PAO-R1, PAO-JP1), Dennis Ohman (PDO111, PDO100), and Matthew R. Parsek (pMRP9-1) for their kind provision of strains or plasmids; Janet Dertien for assistance with the CLSM; and Joanna E. Swickard for critical reading of the manuscript. Strain PW7298::pqsA-lacZ was made available through grant NIH P30 DK089507.

Received: 11 May 2012 Accepted: 6 August 2012

Published: 18 August 2012

\section{References}

1. Gibson RL, Burns JL, Ramsey BW: Pathophysiology and management of pulmonary infections in cystic fibrosis. Am J Respir Crit Care Med 2003, 168:918-951.

2. Rommens JM, lannuzzi MC, Kerem B, Drumm ML, Melmer G, Dean M, Rozmahel R, Cole JL, Kennedy D, Hidaka N, Zsiga M, Buchwald M, Riordan JR, Tsue LC, Collins FS: Identification of the cystic fibrosis gene: chromosome walking and jumping. Science 1989, 245:1059-1065.

3. Baltch AL: Pseudomonas bacteremia. In Pseudomonas aeruginosa infection and treatment. Edited by Smith RP, Baltch AL. New York: Marcel Dekker; 1994:73-128.

4. Jiang C, Finkbeiner WE, Widdicombe JH, McCray PB Jr, Miller SS: Altered fluid transport across airway epithelium in cystic fibrosis. Science 1993, 262:424-427.

5. Hassett DJ, Cuppoletti J, Trapnell B, Lymar SV, Rowe JJ, Yoon SS, Hilliard GM, Parvatiyar K, Kamani MC, Wozniak DJ, Hwang SH, McDermott TR, Ochsner UA: Anaerobic metabolism and quorum sensing by Pseudomonas aeruginosa biofilms in chronically infected cystic fibrosis airways: rethinking antibiotic treatment strategies and drug targets. Adv Drug Deliv Rev 2002, 54:1425-1443.

6. Burns JL, Ramsey BW, Smith AL: Clinical manifestations and treatment of pulmonary infections in cystic fibrosis. Adv Pediatr Infect Dis 1993, 8:53-66.

7. Pier GB, Ramphal R: Pseudomonas aeruginosa. In Mandell, Douglas, and Bennett's Principles and Practice of Infectious Diseases. vol. 2, 7th edition. Edited by Mandell GL, Bennett JE, Dolin R. Philadelphia: Churchill Livingstone; 2010:2835-2860.

8. Lyczak JB, Cannon CL, Pier GB: Lung infections associated with cystic fibrosis. Clin Microbiol Rev 2002, 15:194-222.

9. Donlan RM, Costerton JW: Biofilms: survival mechanisms of clinically relevant microorganisms. Clin Microbiol Rev 2002, 15:167-193.

10. Leid JG, Willson CJ, Shirtliff ME, Hassett DJ, Parsek MR, Jeffers AK: The exopolysaccharide alginate protects Pseudomonas aeruginosa biofilm bacteria from IFN-gamma-mediated macrophage killing. J Immuno/ 2005, 175:7512-7518.

11. Matsukawa M, Greenberg EP: Putative exopolysaccharide synthesis genes influence Pseudomonas aeruginosa biofilm development. J Bacterio/ 2004, 186:4449-4456.

12. Stewart PS, Costerton JW: Antibiotic resistance of bacteria in biofilms. Lancet 2001, 358:135-138.

13. Sauer K, Camper AK, Ehrlich GD, Costerton JW, Davies DG: Pseudomonas aeruginosa displays multiple phenotypes during development as a biofilm. J Bacteriol 2002, 184:1140-1154.

14. Costerton JW, Stewart PS, Greenberg EP: Bacterial biofilms: a common cause of persistent infections. Science 1999, 284:1318-1322.

15. Ghani M, Soothill JS: Ceftazidime, gentamicin, and rifampicin, in combination, kill biofilms of mucoid Pseudomonas aeruginosa. Can J Microbiol 1997, 43:999-1004.

16. Sriramulu DD, Lunsdorf H, Lam JS, Romling U: Microcolony formation: a novel biofilm model of Pseudomonas aeruginosa for the cystic fibrosis lung. J Med Microbiol 2005, 54:667-676.

17. Creeth JM: Constituents of mucus and their separation. Br Med Bull 1978, $34: 17-24$

18. Voynow JA, Rubin BK: Mucins, mucus, and sputum. Chest 2009, 135:505-512.

19. Landry RM, An D, Hupp JT, Singh PK, Parsek MR: Mucin-Pseudomonas aeruginosa interactions promote biofilm formation and antibiotic resistance. Mol Microbiol 2006, 59:142-151.

20. Heydorn A, Nielsen AT, Hentzer M, Sternberg C, Givskov M, Ersboll BK, Molin S: Quantification of biofilm structures by the novel computer program COMSTAT. Microbiology 2000, 146:2395-2407.

21. Worlitzsch D, Tarran R, Ulrich M, Schwab U, Cekici A, Meyer KC, Birrer P, Bellon G, Berger J, Weiss T, et al: Effects of reduced mucus oxygen concentration in airway Pseudomonas infections of cystic fibrosis patients. J Clin Invest 2002, 109:317-325.

22. Schobert $M_{\text {, Jahn }} \mathrm{D}$ : Anaerobic physiology of Pseudomonas aeruginosa in the cystic fibrosis lung. Int J Med Microbiol 2010, 300:549-556.

23. Carty NL, Rumbaugh KP, Hamood AN: Regulation of toxA by PtxR in Pseudomonas aeruginosa PA103. Can J Microbiol 2003, 49:450-464.

24. Liu PV: The roles of various fractions of Pseudomonas aeruginosa in its pathogenesis. III. Identity of the lethal toxins produced in vitro and in vivo. J Infect Dis 1966, 116:481-489.

25. Rumbaugh KP, Griswold JA, Iglewski BH, Hamood AN: Contribution of quorum sensing to the virulence of Pseudomonas aeruginosa in burn wound infections. Infect Immun 1999, 67:5854-5862.

26. Totten PA, Lory S: Characterization of the type a flagellin gene from Pseudomonas aeruginosa PAK. J Bacteriol 1990, 172:7188-7199.

27. Schaber JA, Carty NL, McDonald NA, Graham ED, Cheluvappa R, Griswold JA, Hamood AN: Analysis of quorum sensing-deficient clinical isolates of Pseudomonas aeruginosa. J Med Microbiol 2004, 53:841-853.

28. Davey ME, Caiazza NC, O'Toole GA: Rhamnolipid surfactant production affects biofilm architecture in Pseudomonas aeruginosa PAO1. J Bacteriol 2003, 185:1027-1036.

29. Sakuragi Y, Kolter R: Quorum-sensing regulation of the biofilm matrix genes (pel) of Pseudomonas aeruginosa. J Bacteriol 2007, 189:5383-5386.

30. Shrout JD, Chopp DL, Just CL, Hentzer M, Givskov M, Parsek MR: The impact of quorum sensing and swarming motility on Pseudomonas 
aeruginosa biofilm formation is nutritionally conditional. Mol Microbiol 2006, 62:1264-1277

31. Kessler E, Safrin M, Olson JC, Ohman DE: Secreted LasA of Pseudomonas aeruginosa is a staphylolytic protease. J Biol Chem 1993, 268:7503-7508.

32. Machan ZA, Taylor GW, Pitt TL, Cole PJ, Wilson R: 2-Heptyl-4hydroxyquinoline $\mathrm{N}$-oxide, an antistaphylococcal agent produced by Pseudomonas aeruginosa. J Antimicrob Chemother 1992, 30:615-623.

33. Davies DG, Marques CN: A fatty acid messenger is responsible for inducing dispersion in microbial biofilms. J Bacteriol 2009, 191:1393-1403.

34. Lagendijk EL, Validov S, Lamers GE, de Weert S, Bloemberg GV: Genetic tools for tagging Gram-negative bacteria with mCherry for visualization in vitro and in natural habitats, biofilm and pathogenicity studies. FEMS Microbiol Lett 2010, 305:81-90.

35. Schaber JA, Hammond A, Carty NL, Williams SC, Colmer-Hamood JA, Burrowes BH, Dhevan V, Griswold JA, Hamood AN: Diversity of biofilms produced by quorum-sensing-deficient clinical isolates of Pseudomonas aeruginosa. J Med Microbiol 2007, 56:738-748.

36. Henke MO, John G, Germann M, Lindemann H, Rubin BK: MUC5AC and MUC5B mucins increase in cystic fibrosis airway secretions during pulmonary exacerbation. Am J Respir Crit Care Med 2007, 175:816-821.

37. Li JD, Dohrman AF, Gallup M, Miyata S, Gum JR, Kim YS, Nadel JA, Prince A Basbaum CB: Transcriptional activation of mucin by Pseudomonas aeruginosa lipopolysaccharide in the pathogenesis of cystic fibrosis lung disease. Proc Natl Acad Sci U S A 1997, 94:967-972.

38. Li JD, Feng W, Gallup M, Kim JH, Gum J, Kim Y, Basbaum C: Activation of NF-kappaB via a Src-dependent Ras-MAPK-pp90rsk pathway is required for Pseudomonas aeruginosa-induced mucin overproduction in epithelial cells. Proc Natl Acad Sci U S A 1998, 95:5718-5723.

39. Yan F, Li W, Jono H, Li Q, Zhang S, Li JD, Shen H: Reactive oxygen species regulate Pseudomonas aeruginosa lipopolysaccharide-induced MUC5AC mucin expression via PKC-NADPH oxidase-ROS-TGF-alpha signaling pathways in human airway epithelial cells. Biochem Biophys Res Commun 2008, 366:513-519.

40. Henke MO, John G, Rheineck C, Chillappagari S, Naehrlich L, Rubin BK: Serine proteases degrade airway mucins in cystic fibrosis. Infect Immun 2011, 79:3438-3444.

41. Whitchurch CB, Tolker-Nielsen T, Ragas PC, Mattick JS: Extracellular DNA required for bacterial biofilm formation. Science 2002, 295:1487.

42. Allesen-Holm M, Barken KB, Yang L, Klausen M, Webb JS, Kjelleberg S, Molin $\mathrm{S}$, Givskov M, Tolker-Nielsen T: A characterization of DNA release in Pseudomonas aeruginosa cultures and biofilms. Mol Microbiol 2006 59:1114-1128

43. Brandt T, Breitenstein S, von der Hardt H, Tümmler B: DNA concentration and length in sputum of patients with cystic fibrosis during inhalation with recombinant human DNase. Thorax 1995, 50:880-882.

44. Kim EJ, Sabra W, Zeng AP: Iron deficiency leads to inhibition of oxygen transfer and enhanced formation of virulence factors in cultures of Pseudomonas aeruginosa PAO1. Microbiology 2003, 149:2627-2634.

45. Gaines JM, Carty NL, Tiburzi F, Davinic M, Visca P, Colmer-Hamood JA, Hamood AN: Regulation of the Pseudomonas aeruginosa toxA, regA and $p t x R$ genes by the iron-starvation sigma factor PvdS under reduced levels of oxygen. Microbiology 2007, 153:4219-4233.

46. Davies DG, Parsek MR, Pearson JP, Iglewski BH, Costerton JW, Greenberg EP: The involvement of cell-to-cell signals in the development of a bacterial biofilm. Science 1998, 280:295-298.

47. Ochsner UA, Reiser J: Autoinducer-mediated regulation of rhamnolipid biosurfactant synthesis in Pseudomonas aeruginosa. Proc Natl Acad Sci U S A 1995, 92:6424-6428.

48. Pesci EC, Pearson JP, Seed PC, Iglewski BH: Regulation of las and $r h l$ quorum sensing in Pseudomonas aeruginosa. J Bacteriol 1997, 179:3127-3132.

49. Pamp SJ, Tolker-Nielsen T: Multiple roles of biosurfactants in structural biofilm development by Pseudomonas aeruginosa. J Bacteriol 2007 189:2531-2539.

50. Boles BR, Thoendel M, Singh PK: Rhamnolipids mediate detachment of Pseudomonas aeruginosa from biofilms. Mol Microbiol 2005, 57:1210-1223.

51. Gambello MJ, Iglewski BH: Cloning and characterization of the Pseudomonas aeruginosa lasR gene, a transcriptional activator of elastase expression. J Bacteriol 1991, 173:3000-3009.
52. Macleod SM, Stickler DJ: Species interactions in mixed-community crystalline biofilms on urinary catheters. J Med Microbiol 2007, 56:1549-1557.

53. Stoodley P, Wilson S, Hall-Stoodley L, Boyle JD, Lappin-Scott HM, Costerton JW: Growth and detachment of cell clusters from mature mixed-species biofilms. Appl Environ Microbiol 2001, 67:5608-5613.

54. Qin Z, Yang L, Qu D, Molin S, Tolker-Nielsen T: Pseudomonas aeruginosa extracellular products inhibit staphylococcal growth, and disrupt established biofilms produced by Staphylococcus epidermidis. Microbiology 2009, 155:2148-2156.

55. Ohman DE, Sadoff JC, Iglewski BH: Toxin A-deficient mutants of Pseudomonas aeruginosa PA103: isolation and characterization. Infect Immun 1980, 28:899-908.

56. Wang EW, Agostini G, Olomu O, Runco D, Jung JY, Chole RA: Gentian violet and ferric ammonium citrate disrupt Pseudomonas aeruginosa biofilms. Laryngoscope 2008, 118:2050-2056.

57. Strom MS, Lory S: Cloning and expression of the pilin gene of Pseudomonas aeruginosa PAK in Escherichia coli. J Bacteriol 1986, 165:367-372.

58. Holloway BW, Krishnapillai V, Morgan AF: Chromosomal genetics of Pseudomonas. Microbiol Rev 1979, 43:73-102.

59. Pearson JP, Pesci EC, Iglewski BH: Roles of Pseudomonas aeruginosa las and $r h /$ quorum-sensing systems in control of elastase and rhamnolipid biosynthesis genes. J Bacterio/ 1997, 179:5756-5767.

60. Brint JM, Ohman DE: Synthesis of multiple exoproducts in Pseudomonas aeruginosa is under the control of RhIR-Rhll, another set of regulators in strain PAO1 with homology to the autoinducer-responsive LuxR-LuxI family. J Bacteriol 1995, 177:7155-7163.

61. Jacobs MA, Alwood A, Thaipisuttikul I, Spencer D, Haugen E, Ernst S, Will O, Kaul R, Raymond C, Levy R, Chun-Rong L, Guenthner D, Bovee D, Olson MV, Manoil C: Comprehensive transposon mutant library of Pseudomonas aeruginosa. Proc Natl Acad Sci U S A 2003, 100:14339-14344.

62. Malone CL, Boles BR, Lauderdale KJ, Thoendel M, Kavanaugh JS, Horswill AR: Fluorescent reporters for Staphylococcus aureus. J Microbiol Methods 2009, 77:251-260.

63. Smith A, Iglewski BH: Transformation of Pseudomonas aeruginosa by electroporation. Nucleic Acids Res 1989, 17:10509.

64. Hammond A, Dertien J, Colmer-Hamood JA, Griswold JA, Hamood AN: Serum inhibits $P$. aeruginosa biofilm formation on plastic surfaces and intravenous catheters. J Surg Res 2010, 159:735-746.

65. O'Toole GA, Kolter R: Initiation of biofilm formation in Pseudomonas fluorescens WCS365 proceeds via multiple, convergent signalling pathways: a genetic analysis. Mol Microbiol 1998, 28:449-461.

doi:10.1186/1471-2180-12-181

Cite this article as: Haley et al:: Characterization of biofilm-like structures formed by Pseudomonas aeruginosa in a synthetic mucus medium. BMC Microbiology 2012 12:181.

\section{Submit your next manuscript to BioMed Central and take full advantage of:}

- Convenient online submission

- Thorough peer review

- No space constraints or color figure charges

- Immediate publication on acceptance

- Inclusion in PubMed, CAS, Scopus and Google Scholar

- Research which is freely available for redistribution 